\title{
Export fluxes of dissolved inorganic carbon to the northern Indian Ocean from the Indian monsoonal rivers
}

\author{
Moturi S. Krishna, Rongali Viswanadham, Mamidala H. K. Prasad, Vuravakonda R. Kumari, and \\ Vedula V. S. S. Sarma \\ CSIR - National Institute of Oceanography, Regional Centre, Visakhapatnam, 530017, India \\ Correspondence: Moturi S. Krishna (moturi@nio.org)
}

Received: 4 January 2018 - Discussion started: 9 January 2018

Revised: 15 December 2018 - Accepted: 30 December 2018 - Published: 30 January 2019

\begin{abstract}
Rivers are an important source of dissolved inorganic carbon (DIC) to the adjacent coastal waters. In order to examine the spatial variability in the distribution and major sources of DIC in the Indian monsoonal rivers and to quantify their export flux to the northern Indian Ocean, 27 major and medium-sized rivers were sampled during the discharge period. Significant spatial variability in concentrations of DIC (3.4-73.6 $\left.\mathrm{mg} \mathrm{L}^{-1}\right)$ was observed, and it is attributed to spatial variations in the precipitation pattern, the size of rivers, pollution and lithology of the catchments. The stable isotopic composition of DIC $\left(\delta^{13} \mathrm{C}_{\text {DIC }}\right)$ also showed strong spatial variability $(-13.0 \%$ to $-1.4 \%$ ) in the Indian monsoonal rivers with relatively depleted $\delta^{13} \mathrm{C}_{\text {DIC }}$ values in rivers of the northwest of India $(-11.1 \pm 2.3 \%$ ) and enriched values in the southeast of India $(-3.5 \pm 2.3 \%)$. Results of the linear least-squares regression models of Keeling and Miller-Tan's plots indicated that the chemical weathering of carbonate and silicate minerals by soil $\mathrm{CO}_{2}$ is the major source of DIC in the Indian monsoonal rivers. Spatial variability in the deviation of $\delta^{13} \mathrm{C}_{\mathrm{DIC}}$ from the approximated $\delta^{13} \mathrm{C}$ of the source may probably be due to dominant autotrophic production in rivers of the southeastern region, whereas heterotrophic decomposition of organic matter largely influences the other Indian monsoonal rivers. It is estimated that the Indian monsoonal rivers annually export $\sim 10.3 \mathrm{Tg}$ of DIC to the northern Indian Ocean, of which the major fraction $(75 \%)$ enters into the Bay of Bengal, and the remaining fraction reaches to the Arabian Sea. This is consistent with the freshwater flux, which is 3 times higher for the Bay of Bengal $\left(\sim 378 \mathrm{~km}^{3} \mathrm{yr}^{-1}\right)$ than for the Arabian Sea $\left(122 \mathrm{~km}^{3} \mathrm{yr}^{-1}\right)$. Despite discharge from the Indian monsoonal rivers accounting for only $1.3 \%$ of the global fresh-
\end{abstract}

water discharge, they disproportionately export $2.5 \%$ of the total DIC exported by the world's major rivers. Despite rivers from the region in the southwest (SW) of India exporting DIC that is an order of magnitude lower $\left(0.3 \mathrm{Tg} \mathrm{yr}^{-1}\right)$ than the rivers from other regions of India, the highest yield of DIC was found in the rivers of the SW region of India. It is attributed to intense precipitation $(\sim 3000 \mathrm{~mm})$, favorable natural vegetation of tropical moist deciduous and tropical wet evergreen and semi-evergreen forests, tropical wet climate, high soil organic carbon, and the dominance of red loamy soils in catchments of the rivers of the SW region.

\section{Introduction}

Dissolved inorganic carbon (DIC) is one of the major constituent of carbon species in rivers. DIC in rivers mainly originates from the geogenic (weathering of carbonate and silicate rocks) and biogenic (decomposition of organic matter in soils) sources (Meybeck, 1987; Mook and Tan, 1991; Gaillardet et al., 1999, Dessert et al., 2001; Viers et al., 2007; Raymond et al., 2008; Tamooh et al., 2013). The former consumes atmospheric carbon dioxide $\left(\mathrm{CO}_{2}\right)$, while the latter releases $\mathrm{CO}_{2}$ fixed by the terrestrial plants. In addition to these major sources in the catchment, DIC is also contributed by various physical and biological processes within the rivers. For instance, heterotrophic decomposition of organic matter, photo-oxidation of dissolved organic carbon (DOC), autotrophic respiration and dissolution of atmospheric $\mathrm{CO}_{2}$ contribute DIC to rivers. On the other hand, autotrophic production by aquatic plants (photosynthesis) and evasion of $\mathrm{CO}_{2}$ to atmosphere withdraw DIC from rivers. All these pro- 
cesses in the catchments and within the rivers are strongly coupled to atmospheric $\mathrm{CO}_{2}$, because they act as either sinks or sources of atmospheric $\mathrm{CO}_{2}$ (e.g. Berner et al., 1983; Mook and Tan, 1991; Gaillardet et al., 1999; Richey et al., 2002). The DIC in rivers and its export to the coastal oceans is thus intimately linked to the global carbon cycle (Campeau et al., 2017).

Riverine export fluxes of DIC to coastal regions of the world's oceans have been estimated on the global (Gaillardet et al., 1999) and regional scales (Richey et al., 2002; Wallin et al., 2013; Crawford et al., 2014; Campeau et al., 2014; Kokic et al., 2015) to understand the component of DIC in the global carbon budget. Annual export flux of DIC from the world's major river systems to the global ocean has been estimated as $\sim 327-385 \mathrm{Tg}\left(1 \mathrm{Tg}=10^{12} \mathrm{~g}\right.$; Ludwig et al., 1998; Meybeck and Vorosmarty, 1999). However, many of the regional studies on DIC export fluxes were limited only to the major river systems (e.g. Gaillardet et al., 1999; Joesoef et al., 2017), for example, the Mississippi River (Raymond and Cole, 2003; Raymond et al., 2008; Cai et al., 2008), Yangtze and Pearl rivers (Cai et al., 2008), Congo (Wang et al., 2013) River, etc. Regional studies on the riverine export fluxes of DIC are very important for the global carbon cycle and budget, as the export fluxes are largely dependent on the hydrological, lithological and environmental conditions, which are highly variable on the regional scales. However, DIC measurements are still lacking in several medium-sized rivers from different regions of the world in general, in particular from Asia.

Studies on the sources and export fluxes of DIC from the Indian rivers are very limited. Though DIC measurements were conducted in some Indian estuaries, for example, Mandovi and Zuari (Sarma et al., 2001), Godavari (Sarma et al., 2011), Cochin (Gupta et al., 2009; Bhavya et al., 2018), Hooghly (Mukhopadhyay et al., 2002; Samanta et al., 2015), Mahanadi (Pattanaik et al., 2017) and Chilka (Gupta et al., 2008; Muduli et al., 2013), they were confined only to the internal cycling of DIC and exchange of $\mathrm{CO}_{2}$ at the airwater interface but were not focused on the sources and export fluxes of DIC. The major sources of DIC in the Indian rivers remain unclear, except only a couple of rivers, Krishna (Das et al., 2005; Laskar et al., 2014) and Ganges (Samanta et al., 2015). Further, the quantity of annual DIC export by the Indian rivers to the coastal regions is unknown. Here, we made an attempt to understand the major sources of DIC in the Indian monsoonal rivers (Fig. 1), using $\delta^{13} \mathrm{C}_{\text {DIC }}$ as a potential tracer, and to estimate the riverine export flux of DIC to the northern Indian Ocean from the Indian subcontinent.

The stable isotopic composition of DIC $\left({ }^{13} \mathrm{C}_{\text {DIC }}\right)$ is widely used to identify the major sources of DIC in the aquatic systems (e.g. Singh et al., 2005; Tamooh et al., 2013; Samanta et al., 2015; Zou, 2016). The isotopic composition of DIC originated by dissolution of atmospheric $\mathrm{CO}_{2}$ is about $0 \%$ (Coplen et al., 2002), whereas it is about $-27 \%$ o to $-26 \%$ if the DIC is derived from the oxidation of or-

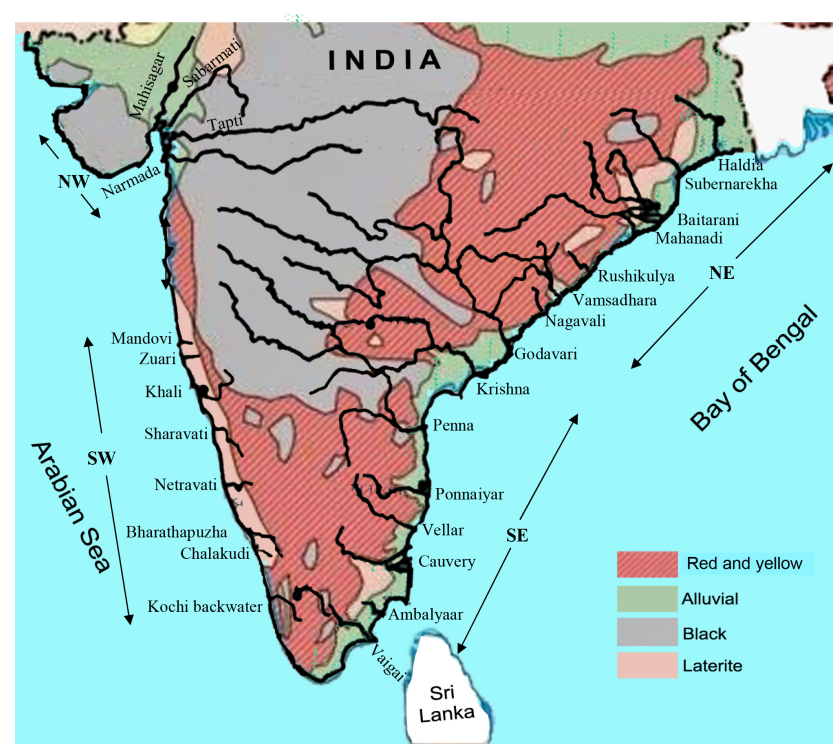

Figure 1. Map showing the study region. Rivers sampled in this study were indicated by solid black line. Distribution of soils in catchments of the Indian monsoonal rivers sampled was also shown. Rivers draining the four regions, i.e., northwest (NW), southwest (SW), southeast (SE) and northeast (NE), were shown by solid black arrows. The source is found at https://www.clearias.com/up/Major soil_types_in_India.jpg (last access: 12 December 2018).

ganic matter produced by $\mathrm{C}_{3}$ plants (O'Leary, 1988). The $\delta^{13} \mathrm{C}$ of DIC generated by the carbonic-acid (formed by soil $\mathrm{CO}_{2}$ dissolution) weathering of silicates is about $-21 \%$ to $-17 \%$ (Solomon and Cerling, 1987), while it is in the range of $-10 \%$ to $-9 \%$ for carbonate rocks, because half of the carbon comes from carbonate rocks (0\%, Land, 1980) during weathering. The weathering of silicate and carbonate minerals yield $\delta^{13} \mathrm{C}_{\text {DIC }}$ in the range of $-8 \%$ to $-7 \%$ o and $-4 \%$ to $-3 \%$, respectively, if the carbonic acid is formed by the dissolution of atmospheric $\mathrm{CO}_{2}$. Though the $\delta^{13} \mathrm{C}$ of DIC derived from different sources is well separable (Deines et al., 1974), the isotopic fractionation by instream physical and biological processes alters the $\delta^{13} \mathrm{C}$ of the DIC source (Fig. 2). For example, photosynthesis and degassing enriches (O'Leary, 1988; Finlay, 2004; Parker et al., 2005, 2010; Polsenaere and Abril, 2012; Venkiteswaran et al., 2014), while the heterotrophic decomposition of organic matter and photo-oxidation of dissolved organic carbon depletes the $\delta^{13} \mathrm{C}$ of DIC (Opsahl and Zepp, 2001; Finlay, 2003; Waldron et al., 2007; Vähätalo and Wetzel, 2008; Fig. 2). Though rivers are generally in disequilibrium with atmospheric $\mathrm{CO}_{2}$ (Raymond et al., 2013) and emit $\mathrm{CO}_{2}$ to atmosphere due to oversaturation (Oquist et al., 2009; Campeau et al., 2017), the isotopic equilibration between the DIC and $\mathrm{CO}_{2}$ in the atmosphere significantly influences the $\delta^{13} \mathrm{C}_{\text {DIC }}$ in rivers (Abongwa and Atekwana, 2014; Deirmendjian and Abril, 2018) due to selective fluxes of ${ }^{12} \mathrm{CO}_{2}$ and ${ }^{13} \mathrm{CO}_{2}$ at the air-water interface. Hence, the influence of biogeochem- 


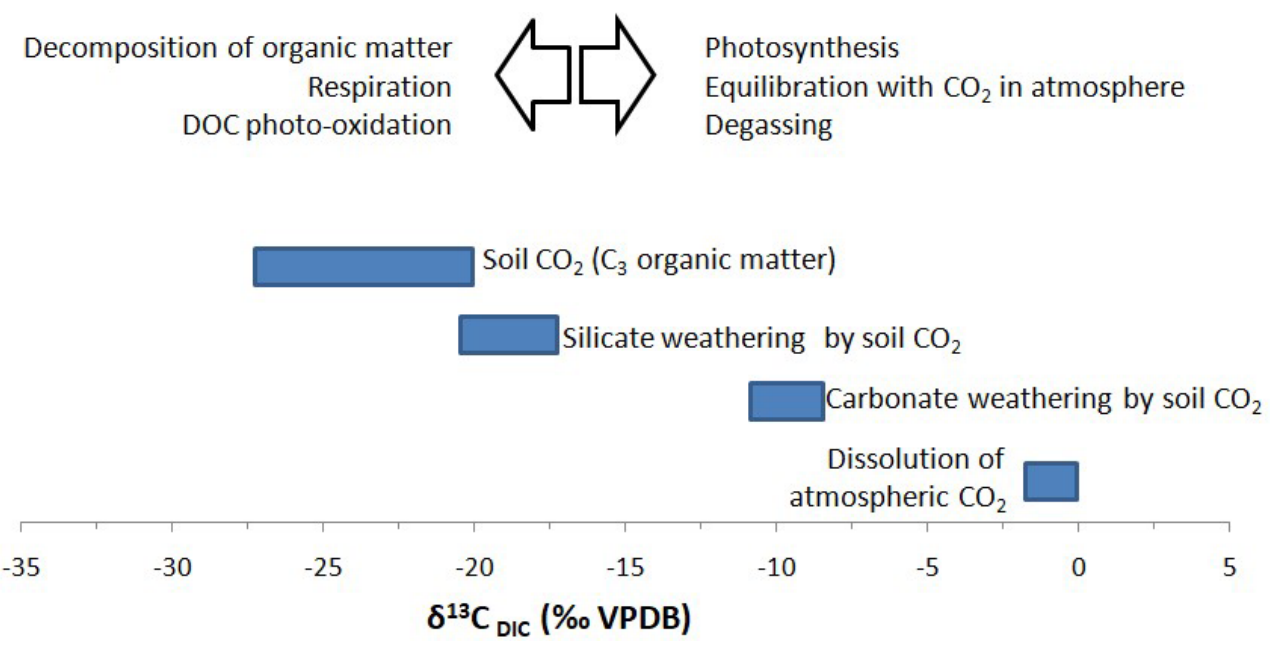

Figure 2. Schematic diagram showing the typical range of $\delta^{13} \mathrm{C}$ of different sources of dissolved inorganic carbon (DIC) in rivers. Various major processes influencing the $\delta^{13} \mathrm{C}$ of DIC $\left(\delta^{13} \mathrm{C}\right.$ DIC $)$ within the rivers were also shown. Black arrows indicate the direction of change in $\delta^{13} \mathrm{C}_{\text {DIC }}$ due to the influences of different in-stream process, mentioned next to the arrows.

ical processes within the rivers must be considered while interpreting the $\delta^{13} \mathrm{C}_{\mathrm{DIC}}$ results for identification of DIC sources. The main objectives of this study are to (i) identify the major sources of DIC in the Indian monsoonal rivers, (ii) estimate the export flux and yield of DIC to the northern Indian Ocean, and (iii) examine the major processes in the catchments and within the rivers controlling DIC in the Indian monsoonal rivers.

\section{Study region, sampling and methods}

\subsection{Study area}

The Indian peninsula bifurcates the northern Indian Ocean into the Bay of Bengal and the Arabian Sea. Although these two basins occupy the same latitudinal belt, their oceanographic processes were reported to be remarkably different due to higher freshwater flux into the Bay of Bengal (1.63 $\times$ $\left.10^{12} \mathrm{~m}^{3} \mathrm{yr}^{-1}\right)$ than into the Arabian Sea $\left(0.3 \times 10^{12} \mathrm{~m}^{3} \mathrm{yr}^{-1}\right.$; Subramanian, 1993; Gauns et al., 2005). The large freshwater influx leads to the formation of a strong vertical salinity stratification in the Bay of Bengal (Varkey et al., 1996) that prevents vertical mixing of nutrient rich subsurface water with the surface (Prasanna Kumar et al., 2004). As a result, the Bay of Bengal is considered to be relatively less productive (Prasanna Kumar et al., 2002) than the adjacent Arabian Sea, which is one of the highly productive zones in the world (Madhupratap et al., 1996; Barber et al., 2001; Smith, 2001) due to injection of nutrients into the surface through the seasonal upwelling and convective mixing (Shetye et al., 1994; Madhupratap et al., 1996; Muraleedharan and Prasanna Kumar, 1996).
Discharge from the Indian monsoonal rivers is largely fed by the monsoon-induced precipitation over the Indian subcontinent, which receives $>80 \%$ of its annual rainfall during the southwest (SW) monsoon period (June-September; Soman and Kumar, 1990). Though some amount of rainfall occurs during the northeast (NE) monsoon (December-March), it does not generate discharge, as it will be stored within the dam reservoirs for domestic, industrial and irrigation purposes. Discharge from the Indian monsoonal rivers mainly occurs during the SW monsoon season (Vijith et al., 2009; Sridevi et al., 2015); hence, these rivers are called monsoonal rivers. Since the major portion of the annual freshwater discharge occurs only during the SW monsoon, the entire estuary is filled with freshwater (Vijith et al., 2009; Sridevi et al., 2015) during this period. As discharge is small during the rest of the year, the discharge during the SW monsoon (wet period) is considered to be equivalent to the annual discharge of the monsoonal rivers. Based on rainfall intensity, forest cover, vegetation and soil type in the catchment, rivers sampled in the present study were categorized into four groups, namely the northwest (NW), SW, southeast (SE) and NE rivers of India (Fig. 1). The SW region of India is characterized by the intense rainfall during SW monsoon $(\sim 3000 \mathrm{~mm})$ following the NE $(1000-2500 \mathrm{~mm})$, SE $(300-500 \mathrm{~mm})$ and NW $(200-500 \mathrm{~mm})$ regions of India (Soman and Kumar, 1990). The SW rivers drain red loamy soils, while the NW rivers drain black soils. Except the major rivers Godavari and Krishna, all the rivers reaching the Bay of Bengal (NE and SE rivers) drain red loamy and alluvial soils in their upper and lower catchments, respectively. The Godavari and Krishna rivers drain black soils in their upper catchment, whereas they drain red loamy and alluvial soils in their middle and lower catchments, respectively (Geological Survey of India; https://www.gsi.gov.in/, last access: 5 
November 2018). Based on discharge, the monsoonal rivers in this study were divided into two types, namely the major $\left(>150 \mathrm{~m}^{3} \mathrm{~s}^{-1}\right)$ and medium-sized $\left(<150 \mathrm{~m}^{3} \mathrm{~s}^{-1}\right)$ rivers.

\subsection{Sample collection}

Water samples were collected from the freshwater regions of the estuaries to obtain reliable export fluxes of DIC to the coastal ocean. Samples were collected at two to three locations to minimize the spatial variability within the freshwater zone of the estuary. Further, to minimize the interannual variability in DIC concentrations, sampling was conducted in 2 different years, and the mean was used for export flux estimations. Further, samples were collected in midstream in the river, using a local mechanized boat to avoid the contamination from river banks.

In situ measurements and sample collection were conducted in 27 rivers of the Indian subcontinent (Fig. 1) during the SW monsoon season of the years 2011 and 2014. Surface water samples at each location were collected for phytoplankton biomass (Chl $a$ ), DIC and dissolved oxygen (DO). Samples for DIC were collected in airtight crimp-top glass bottles, and poison (mercuric chloride) was added to arrest the biological activity. DO analysis was carried out at a temporary shore laboratory setup for sample processing after the completion of sampling on each day. Water samples were filtered through GF/F (nominal pore size of $0.7 \mu \mathrm{m}$ ) under moderate vacuum and were stored in liquid nitrogen for Chl $a$ analysis.

\subsection{Methods}

Temperature and salinity at the sampling locations were measured using a conductivity-temperature-density (CTD) profiling system (Sea Bird Electronics, SBE 19plus, United States of America). Concentration of DO was determined by Winkler's method (Carritt and Carpenter, 1966) using an auto titrator (Metrohm, Switzerland) with potentiometric endpoint detection. The analytical precision of the method was $\pm 0.07 \%$ (RSD). Dissolved oxygen saturation is computed following formulations given by Garcia and Gordon (1992). DIC concentrations in water samples were measured at our institute's laboratory using a coulometer (UIC Inc., USA) connected to an automatic subsampling system. Based on the repeated analysis of samples and standards, the precision of the method was $\pm 0.02 \mathrm{mg} \mathrm{L}^{-1}$. The certified reference materials (CRMs) supplied by Andrew G. Dickson from Scripps Institute of Oceanography, USA, and internal standards were used to test the accuracy of our DIC measurements; they were found to be within $\pm 0.2 \%$ to $0.3 \%$. The potentiometric Gran titration method (Metrohm, Switzerland) was used for determination of $\mathrm{pH}$ and total alkalinity and followed the standard operating procedures given by the Department of Energy (DOE; 1998).
The stable carbon isotopic composition of DIC in the water was measured on a gas-bench-isotope-ratio mass spectrometer (EA-IRMS-Delta V, Finnigan, Germany). $50 \mathrm{~mL}$ airtight bottles with rubble septa were filled with $0.5 \mathrm{~mL}$ of high-purity orthophosphoric acid and purged with highpurity helium. About $1 \mathrm{~mL}$ of a water sample is injected into the bottle and incubated at constant temperature of $50^{\circ} \mathrm{C}$ for $12 \mathrm{~h}$. The $\mathrm{CO}_{2}$ extracted into the head space is injected into the IRMS through gas bench. The results are expressed relative to conventional standards, that is, with Pee Dee Belemnite (PDB) limestone for carbon (Coplen, 1996) as $\delta$ values, defined as

$\delta R=\left[(X\right.$ sample $-X$ standard $) /(X$ standard $\left.) \times 10^{3}\right] \%$,

where $R$ refers to ${ }^{13} \mathrm{C}$, and $X$ stands for ${ }^{13} \mathrm{C} /{ }^{12} \mathrm{C}$. The highpurity tank of $\mathrm{CO}_{2}$ was used as a working standard for carbon. These gases were calibrated with standards of the International Atomic Energy Agency (IAEA). Standard deviation on 20 aliquots of the same sample was lower than $0.05 \%$ for $\delta^{13} \mathrm{C}$. Chlorophyll $a(\mathrm{Chl} a)$ on the filter was extracted into dimethylformamide (DMF) and measured the extract fluorometrically using a spectrofluorophotometer (Varian Eclipse, Varian Electronics, UK) following Suzuki and Ishimaru (1990). Annual mean discharge data of the rivers were taken from Meybeck and Ragu $(1995,1996)$, the Central Water Commission of New Delhi $(2006,2012)$, and Kumar et al. (2005). Catchment area of the rivers was obtained from Water Resources Information System of India (WRIS, http://www.india-wris.nrsc.gov.in/, last access: 10 October 2018). Soil organic carbon data were taken from Kishwan et al. (2009) and Sreenivas et al. (2016), and the rainfall data were obtained from Soman and Kumar (1990). Dissolved organic carbon (DOC) data for the Indian rivers were taken from Krishna et al. (2015)

Total export flux of DIC from each river was estimated by multiplying the mean concentrations of DIC at near-zero salinity (river endmember) with the annual discharge. Spatial variability of DIC concentrations within the river was minimized to a large extent by collecting samples from two to three locations in each river, while the interannual variability was minimized by collecting samples during discharge periods of 2 years. However, variability in DIC concentrations within the discharge period results in some uncertainties in our estimations of DIC export fluxes. Time series measurements in the Godavari estuary (our unpublished results) revealed that the variability in DIC concentrations within the discharge period is up to $10 \%$. Therefore, the error associated with our DIC flux estimates may be about $10 \%$. The DIC flux normalized by catchment area (yield) was calculated by dividing the total DIC export flux of the river by its catchment area. 


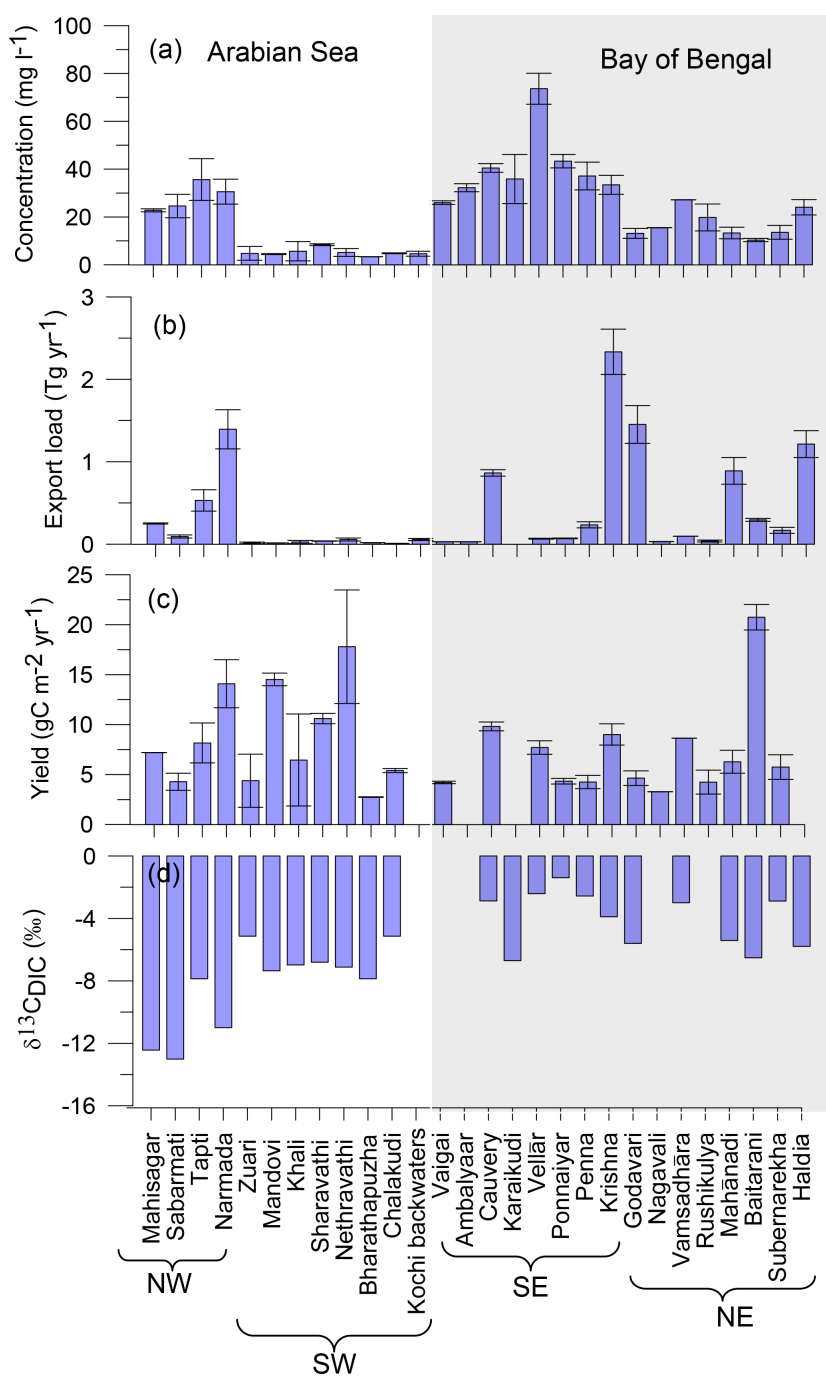

Figure 3. Spatial variability in the concentration $\left(\mathrm{mgL}^{-1}\right.$; a), export flux $\left(\mathrm{Tg} \mathrm{yr}^{-1} ; \mathbf{b}\right)$ and yield $\left(\mathrm{g} \mathrm{m}^{-2} \mathrm{yr}^{-1} ; \mathbf{c}\right)$ of dissolved inorganic carbon (DIC) and its stable isotopes $\left(\delta^{13} \mathrm{C}_{\text {DIC }} ; \mathbf{d}\right)$ in the Indian monsoonal rivers studied. Rivers geographically located in the northwest (NW), southwest (SW), southeast (SE) and northeast (NE) regions of India were also shown. Rivers draining into the Bay of Bengal (east-flowing rivers) were shown with gray shading, while rivers draining into the Arabian Sea (west-flowing) were shown with no shading.

\section{Results}

\subsection{Hydrographic characteristics}

Surface water temperatures were higher in rivers from the $\mathrm{NE}$ and SE regions (mean $30.9 \pm 1.2^{\circ} \mathrm{C}$ ) than the rivers from the SW and NW regions $\left(27.3 \pm 1.5^{\circ} \mathrm{C}\right)$ of India. Dissolved oxygen saturation varied, from as low as $63 \%$ to as high as $105 \%$, with a mean saturation of $90 \pm 11 \%$. The rivers from the SW region of India recorded more undersaturation of DO $(82 \pm 7 \%)$ than the rivers located in the $\mathrm{NE}$
$(89 \pm 15 \%), \mathrm{NW}(93 \pm 3 \%)$ and $\mathrm{SE}(96 \pm 11 \%)$ regions of India. Chlorophyll $a(\mathrm{Chl} a)$ concentrations varied broadly, from 0.8 to $7.5 \mathrm{mg} \mathrm{m}^{-3}$, with relatively higher mean concentrations in rivers of the SE region $\left(4.7 \pm 2.5 \mathrm{mg} \mathrm{m}^{-3}\right)$ followed by the SW $\left(2.8 \pm 0.7 \mathrm{mg} \mathrm{m}^{-3}\right)$ regions of India. On the other hand, relatively low Chl $a$ was observed in the mediumsized $\left(2.6 \pm 1.3 \mathrm{mg} \mathrm{m}^{-3}\right)$ when compared to the major estuaries $\left(3.2 \pm 2.1 \mathrm{mg} \mathrm{m}^{-3}\right)$.

\subsection{DIC concentrations and $\delta^{13} \mathrm{C}_{\text {DIC }}$}

DIC concentrations in the Indian monsoonal rivers widely varied, from 3.4 (Bharathapuzha) to $73.6 \mathrm{mg} \mathrm{L}^{-1}$ (Vellar), with a significant spatial variability (Fig. 3a; Table 1). The highest mean DIC concentration was observed in rivers of the $\mathrm{SE}$ region $\left(37.4 \pm 6.3 \mathrm{mg} \mathrm{L}^{-1}\right)$, while the lowest DIC was found in the SW region $\left(5.2 \pm 2.1 \mathrm{mg} \mathrm{L}^{-1}\right)$ of India. Intermediate values were found in rivers of the NW (28.4 \pm $\left.8.9 \mathrm{mg} \mathrm{L}^{-1}\right)$ and $\mathrm{NE}\left(17.1 \pm 6.2 \mathrm{mg} \mathrm{L}^{-1}\right)$ regions of India. DIC concentrations were found to be similar in the major $\left(22.7 \pm 13.6 \mathrm{mg} \mathrm{L}^{-1}\right)$ and medium $\left(21.1 \pm 13.2 \mathrm{mg} \mathrm{L}^{-1}\right)$ rivers (homoscedastic Student's $t$ test; $p=0.76$ ). The mean DIC concentration found in this study $\left(21.4 \pm 16.3 \mathrm{mg} \mathrm{L}^{-1}\right)$ is similar to those observed earlier in the major river systems of India (Brahmaputra; Singh et al., 2005) and elsewhere in the world, for example, in British rivers (Jarvie et al., 2017) and Swedish rivers (Campeau et al., 2017). However, DIC concentrations in the present study are higher than the global mean DIC $\left(10.3 \mathrm{mg} \mathrm{L}^{-1}\right.$, Meybeck and Vorosmarty, 1999; Table 1) but are lower than those reported in the rivers draining into the Gulf of Trieste (northern Adriatic; 37-66 $\mathrm{mg} \mathrm{L}^{-1}$; Tamse et al., 2014).

The $\delta^{13} \mathrm{C}_{\text {DIC }}$ varied from -13.0 to $-1.4 \%$, with a significant spatial variability (Fig. 3d; Table 1) in the rivers sampled. Relatively depleted $\delta^{13} \mathrm{C}_{\text {DIC }}$ values were observed in rivers of the NW region $(-11.1 \pm 2.3 \%$ ), while enriched $\delta^{13} \mathrm{C}_{\text {DIC }}$ was found in rivers of the SE region $(-3.5 \pm 2.3 \%$ ) of India (Fig. 3d). The $\delta^{13} \mathrm{C}_{\text {DIC }}$ values found in this study are well within the range of values reported earlier in rivers of India (Das et al., 2005) and elsewhere in the world, for example, in Swedish streams ( $-27.6 \%$ o to $-0.6 \%$; Campeau et al., 2017) and rivers from Italy and Slovenia $(-12.8 \%$ to $-7.7 \%$, Tamse et al., 2014).

\subsection{Export fluxes and yield of DIC}

Annual export flux of DIC to the coastal ocean from the individual rivers varied broadly from $0.01 \mathrm{Tg}$ (Chalakundi) to as high as $2.33 \mathrm{Tg}$ (Krishna; Fig. 3b; Table 1). Among the rivers sampled, rivers of the NE region of India export higher DIC $\left(6.52 \mathrm{Tg} \mathrm{yr}^{-1}\right)$ while the lowest was found from rivers of the $\mathrm{SW}$ region $\left(0.24 \mathrm{Tg} \mathrm{yr}^{-1}\right.$; Table 1$)$. The Indian monsoonal rivers together export about $10.32 \mathrm{Tg} \mathrm{yr}^{-1}$ of DIC to the northern Indian Ocean, of which $7.81 \mathrm{Tg}(75 \%)$ enters into the Bay of Bengal, and the remaining enters into 


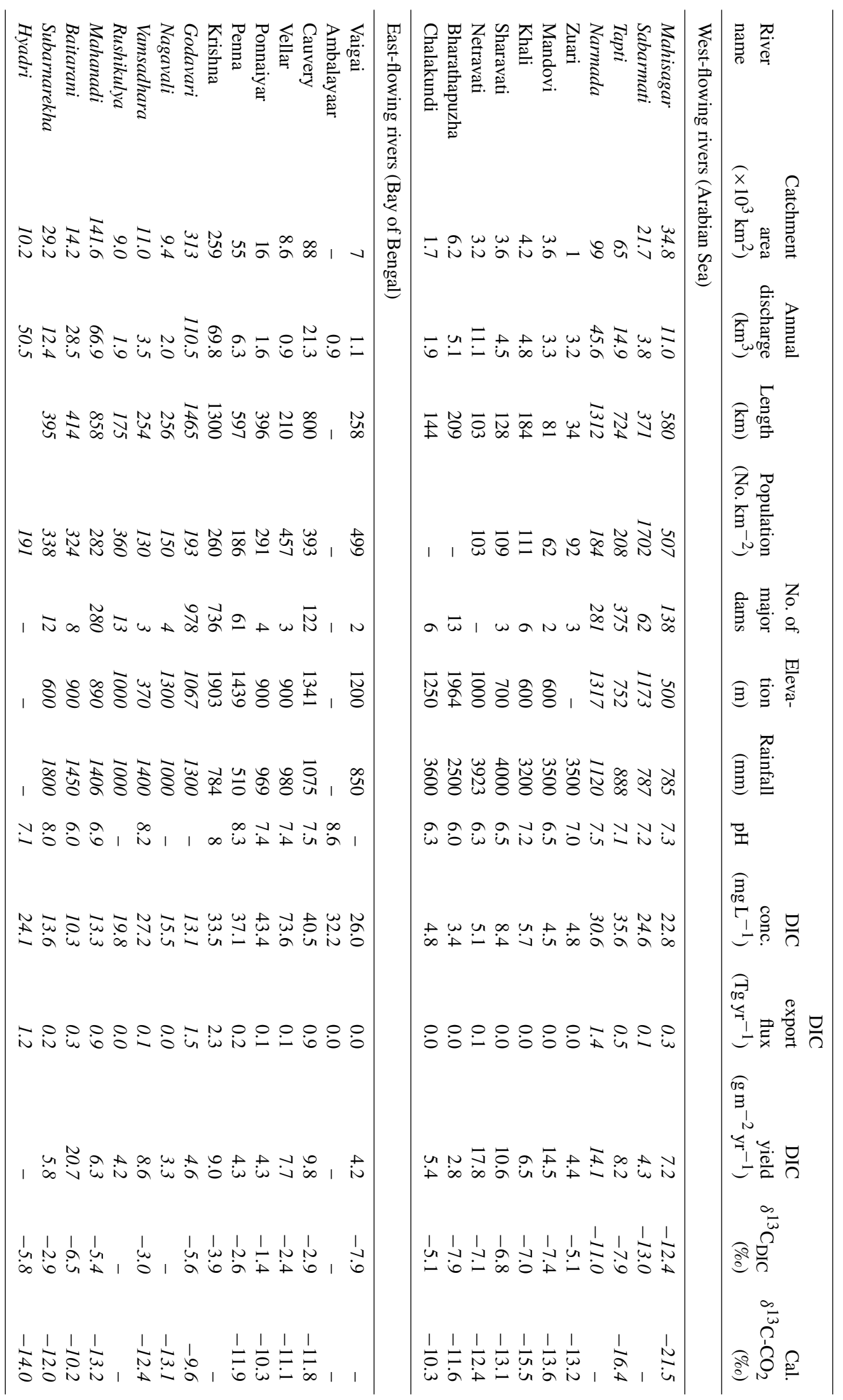

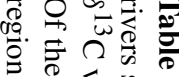
要 言䨔. उᄋ ? . $\Rightarrow$

is $\overline{0}$. 융. $\stackrel{x}{\rightarrow}$

륭요

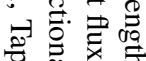

․․료. 谷产 乙

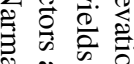

ڤ

융

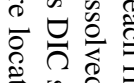

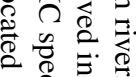
․ 政.

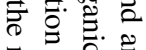
해융 $\underset{1}{2} \circ$ के 뭉 建莃言

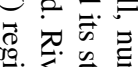
용. 징 $\frac{n}{0}$

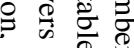
छ क्ष ㄹ. $\Xi$. के $\Rightarrow \overline{0} 0$ 훙 웡 象号. 范志

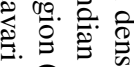
응․․

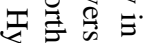
芯. 용 के $\overrightarrow{0}$

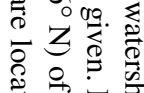

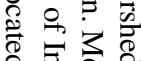
要.

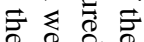

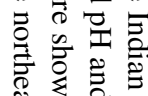

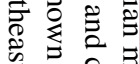

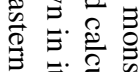

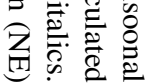


the Arabian Sea $(2.51 \mathrm{Tg})$. The yield of DIC ranged from 2.8 (Bharathapuzha) to $20.7 \mathrm{~g} \mathrm{~m}^{-2} \mathrm{yr}^{-1}$ (Baitarani; 3c; Table 1), excluding the exceptionally high yield of $119 \mathrm{~g} \mathrm{~m}^{-2}$ $\mathrm{yr}^{-1}$ from the Haldia River. The mean yield was found to be more or less similar in rivers from all the four regions of India, i.e, the NW $\left(8.4 \mathrm{~g} \mathrm{~m}^{-2} \mathrm{yr}^{-1}\right)$, SW $\left(8.8 \mathrm{~g} \mathrm{~m}^{-2} \mathrm{yr}^{-1}\right)$, SE $\left(6.6 \mathrm{~g} \mathrm{~m}^{-2} \mathrm{yr}^{-1}\right)$ and NE $\left(7.7 \mathrm{~g} \mathrm{~m}^{-2} \mathrm{yr}^{-1}\right)$ regions. Despite the export flux of DIC being lowest from rivers of the SW region $\left(0.24 \mathrm{Tg} \mathrm{yr}^{-1}\right)$, interestingly, the yield from rivers of this region is on par with (even slightly higher than) the other Indian monsoonal rivers (Table 1; Fig. 3b, c). Yields of DIC found in this study are similar to those found earlier in rivers elsewhere in the world (Huang et al., 2012).

\section{Discussion}

\subsection{Distribution of DIC in the Indian monsoonal rivers}

Distribution of DIC in the Indian monsoonal rivers showed large spatial variability, with the lowest values in rivers from the SW region of India (Fig. 3a). DIC concentrations in rivers are known to be influenced by the intensity of precipitation over the catchment, basin lithology (Giesler et al., 2013; Löfgren et al., 2014), length of the fluvial network (Hotchkiss et al., 2015), and in-stream physical and biological processes (Mook and Tan, 1991; Raymond et al., 2008). The spatial distribution of rainfall over the Indian subcontinent (http://www.imd.gov.in, last access: 8 October 2018) shows that the SW region receives the highest annual rainfall $(\sim 3000 \mathrm{~mm}$ ) when compared to the rest of India (Soman and Kumar, 1990).

The intense precipitation over the SW region is expected to cause higher weathering rates and thus higher DIC in rivers (e.g., Gupta et al., 2011), but lower DIC concentrations were found in rivers of this region. It could be due to the influence of dilution, because the dense precipitation over the small catchment area (Table 1) might have diluted DIC concentrations in rivers of this region. In order to understand the influence of the density of rainfall on DIC in rivers, we normalized the volume of discharge from the river with its catchment area. The catchment area-normalized volume of discharge was found to be much higher in rivers from the SW region $\left(1.71 \mathrm{~m}^{3} \mathrm{~m}^{-2}\right)$ than the rivers from the SE $\left(0.17 \mathrm{~m}^{3} \mathrm{~m}^{-2}\right)$, NE $\left(0.6 \mathrm{~m}^{3} \mathrm{~m}^{-2}\right)$ and NW $\left(0.32 \mathrm{~m}^{3} \mathrm{~m}^{-2}\right)$ regions of India. Higher catchment area-normalized discharge (about 3 times) might have diluted DIC concentrations in the rivers of the former region. A strong exponential decrease in DIC concentrations with increasing rainfall over the catchment $\left(r^{2}=0.72, p<0.001\right.$; Fig. $\left.4 a\right)$ also suggests that DIC concentration in the Indian rivers is strongly influenced by density of precipitation over the catchment. Rivers of the SW region are relatively small in size, both in terms of catchment area (total catchment area: $20 \mathrm{~km} \times 10^{3} \mathrm{~km}$ ) and the length of the river (mean length: $126 \mathrm{~km}$ ), when compared to the rivers from other regions (SE, NE and NW) of India (Table 1). Since the contribution of DIC from in-stream processes, such as decomposition of organic matter, has been demonstrated to increase along the course of the fluvial network (Hotchkiss et al., 2015), possibly due to an increase in the residence time of water (Catalan et al., 2016), the lowest DIC concentrations found in rivers from the SW region may also, at least partly, be due to their small size. Fairly good positive correlation between DIC concentrations and length of the rivers $\left(r^{2}=0.38, p<0.01\right.$; Fig. $\left.4 \mathrm{~b}\right)$ also supports this argument.

The major physical and biological processes controlling DIC concentrations in rivers are the exchange of $\mathrm{CO}_{2}$ with the atmosphere, autotrophic removal and heterotrophic addition of DIC. Since the Indian monsoonal estuaries have been reported to be a source of $\mathrm{CO}_{2}$ to the atmosphere during the discharge period due to heterotrophic decomposition of organic matter (Sarma et al., 2001, 2011, 2012; Gupta et al., 2008, 2009; Bhavya et al., 2018), the DIC input from the dissolution of atmospheric $\mathrm{CO}_{2}$ may be unlikely. On the other hand, organic matter decomposition is expected to add a significant amount of DIC, as enhanced bacterial respiration rates were reported during this period (Sarma et al., 2011, 2012). In contrast, significant negative correlation between chlorophyll $a$ and DIC ( $r^{2}=-0.44, p<0.01$; Fig. $\left.4 \mathrm{c}\right)$, except few SE rivers where elevated phytoplankton biomass (Chl $a>5 \mathrm{mg} \mathrm{m}^{-3}$ ) was recorded, suggests that autotrophic removal of DIC is also significant in the Indian monsoonal rivers during the study period. A significant positive relationship was observed between the $\delta^{13} \mathrm{C}_{\mathrm{DIC}}$ and Chl $a\left(r^{2}=\right.$ $0.49 ; p<0.01$; Fig. $4 d$ ), supporting this argument, because preferential uptake of ${ }^{12} \mathrm{C}$ over ${ }^{13} \mathrm{C}$ during photosynthesis leaves the residual DIC enriched in ${ }^{13} \mathrm{C}$. On the other hand, $\delta^{13} \mathrm{C}_{\text {DIC }}$ showed significant positive correlation with DO saturation $\left(r^{2}=0.50, p<0.01\right.$; Fig. $4 \mathrm{e}$; depleted $\delta^{13} \mathrm{C}_{\text {DIC }}$ values with more undersaturation of DO) and DOC concentrations $\left(r^{2}=0.43, p<0.01\right.$; Fig. $\left.4 \mathrm{f}\right)$, as was observed in the $\mathrm{Xi}$ river (Zou et al., 2016). Altogether, enriched $\delta^{13} \mathrm{C}_{\text {DIC }}$ values are associated with higher DOC, less undersaturation of DO and higher phytoplankton biomass $(\mathrm{Chl} a)$, while the depleted $\delta^{13} \mathrm{C}_{\text {DIC }}$ values are associated with more undersaturation of DO and less DOC. This suggests that both autotrophic removal and heterotrophic addition control DIC in the Indian rivers during the discharge period, with a considerable spatial variability. However, the influence of these processes on DIC concentrations is difficult to separate with this bulk $\delta^{13} \mathrm{C}_{\mathrm{DIC}}$ data set, as the $\delta^{13} \mathrm{C}_{\text {DIC }}$ in rivers is also influenced by pollution, catchment lithology and outgassing of $\mathrm{CO}_{2}$ (Brunet et al., 2005; Bouillon et al., 2009; Shin et al., 2011; Zeng et al., 2011; Tamooh et al., 2013). Excluding Sabarmati and Mahisagar rivers, DIC concentrations showed a fairly good linear relationship with population density over the catchment of the river $\left(r^{2}=0.41, p<0.01\right.$; Fig. $\left.4 \mathrm{~g}\right)$, suggesting a considerable influence of pollution from the megacities and industries on DIC in the Indian rivers. 

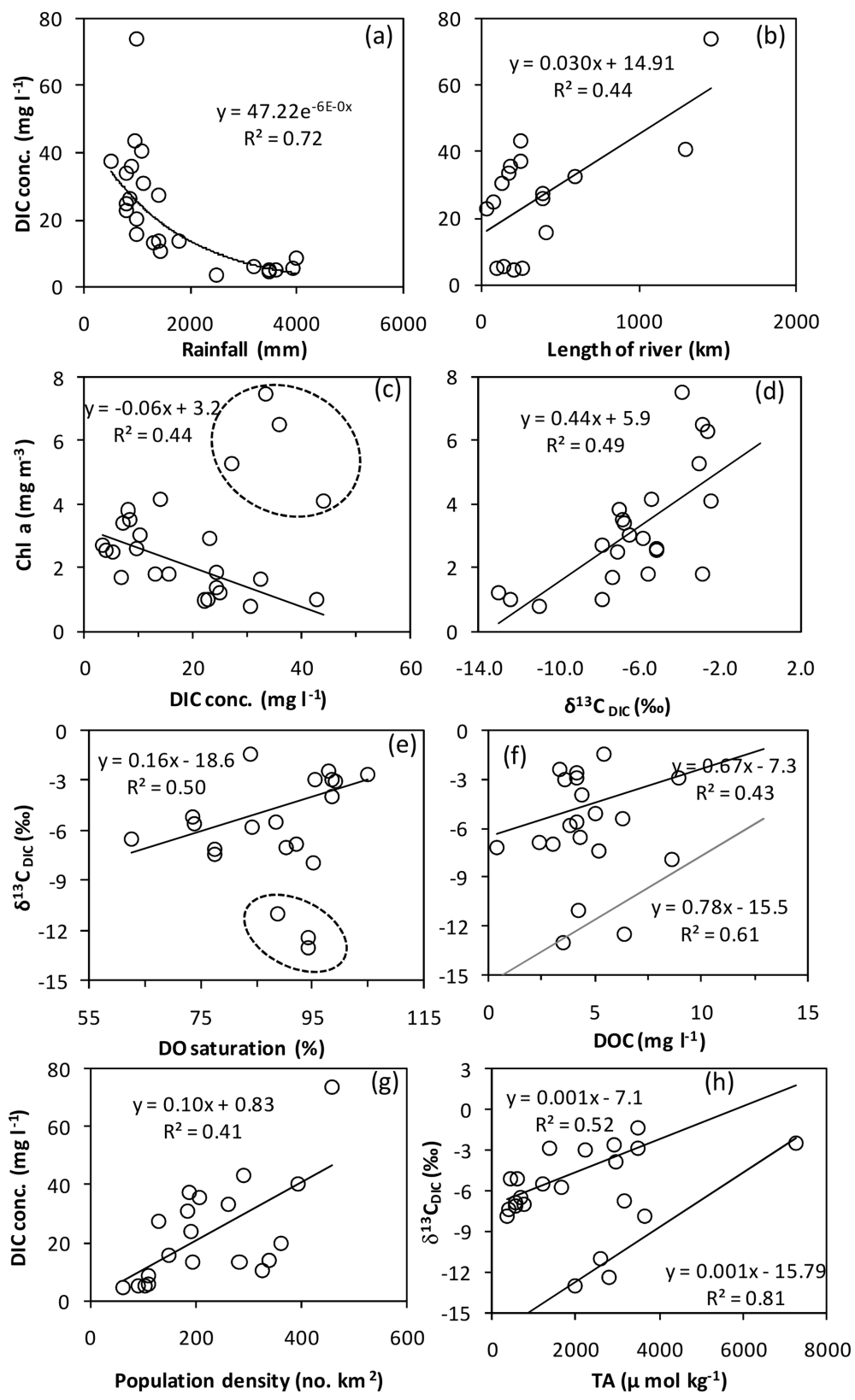

Figure 4. (a) Exponential decrease and (b) linear increase of dissolved inorganic carbon (DIC) concentrations with increasing rainfall over the catchment and the length of the river, respectively. (c) Inverse and (d) linear relationships of chlorophyll $a$ (Chl $a$ ) with concentrations and $\delta^{13} \mathrm{C}$ of DIC, respectively. Significant linear relationships of $\delta^{13} \mathrm{C}$ of DIC with (e) dissolved oxygen (DO) saturation and (f) dissolved organic carbon (DOC) concentration. Linear relationships observed between (g) DIC concentrations and population density in the catchment, and (h) total alkalinity and $\delta^{13} \mathrm{C}$ of DIC in the Indian monsoonal rivers during the study period. Ovals with dashed lines indicate the outliers which were not included in the regression equations. Rivers of the northwestern region of India showed linear relationships, as shown by the other Indian rivers but with a different slope (f-h).

Spatial distribution of soils shows that rivers of the NW region of India and upper reaches of Krishna and Godavari rivers drain the lime-rich black soils (Fig. 1), while rivers from the SW region drain red loamy soils, whereas the eastflowing rivers drain the lime-poor red sandy soils in the upper but lime-rich alluvial soils in the lower reaches (Fig. 1).
Lateritic soils, which are poor in lime and silicate, occupied the catchment of the rivers in the SW region of India. Relatively lower chemical weathering rates of the lateritic than the non-lateritic soils could be one of the reasons for the observed lower DIC concentration in the rivers from the SW region of India. A significant positive correlation was found be- 

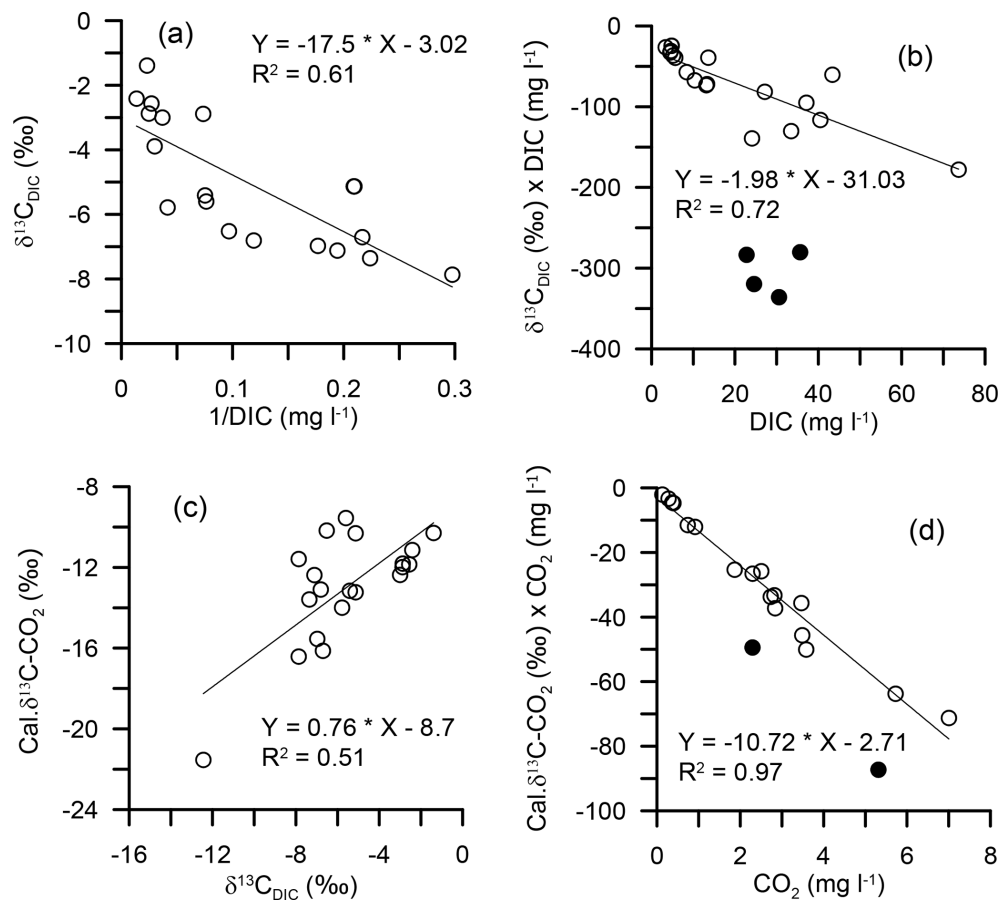

Figure 5. Linear least-squares regression models of (a) $\delta^{13} \mathrm{C}_{\text {DIC }}$ as a function of 1/DIC (Keeling plot) and (b) $\delta^{13} \mathrm{C}_{\mathrm{DIC}} \mathrm{xDIC}$ as a function of DIC concentrations (Miller-Tans plot) in the Indian monsoonal rivers. (c) Linear relationship between calculated $\delta^{13} \mathrm{C}$ of $\mathrm{CO}_{2}$ and the measured $\delta^{13} \mathrm{C}_{\mathrm{DIC}}$ values, and (d) Miller-Tans linear regression model of $\delta^{13} \mathrm{C}_{-} \mathrm{CO}_{2} \times \mathrm{CO}_{2}$ as a function of $\mathrm{CO}_{2}$ concentration in the Indian monsoonal rivers.

tween total alkalinity (TA) and $\delta^{13} \mathrm{C}_{\text {DIC }}\left(r^{2}=0.52 ; p<0.01\right.$; Fig. 4h), suggesting that a significant contribution of DIC is from weathering of carbonate minerals in the catchment. Though the higher chemical weathering rates were reported for the Deccan Trap basalts (Das et al., 2005; Singh et al., 2005), which occupied the catchments of rivers of the NW region of India and upper reaches of Godavari and Krishna, higher DIC concentrations were also observed in rivers draining over the metamorphic rocks. This suggests that the influences of factors other than bedrock are also significant in the concentrations of DIC in the Indian rivers.

\subsection{Major sources of DIC in the Indian monsoonal rivers}

Though the $\delta^{13} \mathrm{C}_{\mathrm{DIC}}$ is a promising tool for deciphering the sources of DIC, its interpretation for source material identification in rivers is still challenging, because multiple physical and biological processes within the rivers significantly alter the $\delta^{13} \mathrm{C}$ of DIC source. The influence of major in-stream processes on the $\delta^{13} \mathrm{C}_{\mathrm{DIC}}$ must be separated before interpreting the results for major sources of DIC, and failing to do this leads to erroneous conclusions. In order to identify and separate DIC sources, here we used two different graphical mixing model techniques, the Keeling (Keeling, 1958; Pataki et al., 2003) and Miller-Tans plots (Miller and Tans, 2003). These models approximate the hypothetical $\delta^{13} \mathrm{C}$ of source material as an intercept (in Keeling plot) and slope (in Miller-Tans plot) of the linear least-squares regression equations (Pataki et al., 2003; Campeau et al., 2017). The deviations from the approximated $\delta^{13} \mathrm{C}$ of the source can be interpreted as the influence of the in-stream processes. Further, we approximated the $\delta^{13} \mathrm{C}_{\text {of }} \mathrm{CO}_{2}$ using a set of enrichment factors of isotopic fractionation across the carbonate species (Zhang et al., 1995) in order to filter the impact of DIC speciation and $\mathrm{pH}$ on the bulk $\delta^{13} \mathrm{C}_{\text {DIC }}$ values. This approach has already been used by Quay et al. (1992), Mayorga et al. (2005) and recently by Campeau et al. (2017).

Significant negative relationships were observed in both the Keeling plot $\left({ }^{13} \mathrm{C}_{\mathrm{DIC}}\right.$ as a function of 1/DIC; Fig. 5a) and the Miller-Tans plot $\left(\delta^{13} \mathrm{C}_{\mathrm{DIC}} \times \mathrm{DIC}\right.$ as a function of DIC; Fig. $5 \mathrm{~b} ; r^{2}=0.61, p<0.01$, and $r^{2}=0.72, p<0.01$, respectively) of DIC in the Indian rivers, except in the rivers draining the Deccan Trap basalts. Both graphical mixing models, the Keeling and Miller-Tan's plot, approximated the similar $\delta^{13} \mathrm{C}$ of source material $(-3.0 \%$ and $-2.0 \%$, respectively; Fig. 5a, b), suggesting that weathering of carbonate minerals is the predominant source of DIC in the Indian monsoonal rivers rather than biogenic soil $\mathrm{CO}_{2}$. Calculated $\delta^{13} \mathrm{C}$ of $\mathrm{CO}_{2}$ ranged from $-21.5 \%$ to $-9.6 \%$ in the Indian rivers, with a mean value of $-13.0 \pm 2.7 \%$. Calculated $\delta^{13} \mathrm{C}$ of $\mathrm{CO}_{2}$ is linearly correlated with the measured $\delta^{13} \mathrm{C}_{\text {DIC }}$, but correlation coefficient $\left(r^{2}\right)$ is only 0.51 (Fig. $5 \mathrm{c}$ ), suggesting significant spatial variability in the influence of in-stream pro- 
cesses on the $\delta^{13} \mathrm{C}_{\mathrm{DIC}}$. The Miller-Tans plot of $\mathrm{CO}_{2}\left(\delta^{13} \mathrm{C}-\right.$ $\mathrm{CO}_{2} \times \mathrm{CO}_{2}$ as a function of $\mathrm{CO}_{2}$ ) showed a highly significant linear regression model with a slope of $-10.7 \% \circ\left(r^{2}=\right.$ $0.97 ; p<0.001 ;$ Fig. $5 d$ ). These results indicated that chemical weathering of carbonate and silicate minerals by soil $\mathrm{CO}_{2}(-10 \%$ o to $-9 \%$ ) is the major source of DIC in the Indian rivers. Deviations of the measured $\delta^{13} \mathrm{C}_{\mathrm{DIC}}(-13.0 \%$ o to $-1.4 \%$ ) from that of the approximated $\delta^{13} \mathrm{C}$ of DIC source $\left(-3.0 \%\right.$ to $-2.0 \%$ ) and $\delta^{13} \mathrm{C}$ of $\mathrm{CO}_{2}(-10.7 \%$ ) could be due to the influence of in-stream process. In more than $75 \%$ of the Indian rivers sampled, the deviation from the $\delta^{13} \mathrm{C}$ of the DIC source is towards the negative side (depletion; $\delta^{13} \mathrm{C}_{\mathrm{DIC}}<-3.0 \%$ ), suggesting that heterotrophic decomposition of organic matter is the dominant process controlling DIC in these rivers. While a lack of (or very little) deviation was observed only in rivers from the SE region of India (mean $\delta^{13} \mathrm{C}_{\mathrm{DIC}}$ : $-3.1 \%$ ), this could be due to the competition between autotrophy, degassing and heterotrophy, as these processes influence the $\delta^{13} \mathrm{C}_{\mathrm{DIC}}$ in opposite directions (Fig. 2); the former two processes cause enrichment, while the latter depletes $\delta^{13} \mathrm{C}_{\text {DIC }}$. Relatively higher phytoplankton biomass (mean $\mathrm{Chl} a: 4.6 \mathrm{mg} \mathrm{m}^{-3}$ ) and less undersaturation of DO $(98.7 \%)$ was observed in these rivers compared to the mean of the rest of the Indian rivers $\left(2.4 \mathrm{mg} \mathrm{m}^{-3}\right.$ and $87.5 \%$, respectively), suggesting that autotrophy is one of the dominant processes controlling DIC in rivers from the $\mathrm{SE}$ region of India. The total number of dams on the rivers from this (SE) region (mean 155, Table 1) is not significantly higher from that of the mean of total number of dams on the Indian rivers sampled (mean 135), suggesting that degassing due to storage of water may not be the dominant process responsible for enrichment in $\delta^{13} \mathrm{C}_{\mathrm{DIC}}$ values of these rivers.

\subsection{Total DIC export by the Indian monsoonal rivers to the northern Indian Ocean}

Indian monsoonal rivers annually export $\sim 10.3 \mathrm{Tg}$ of DIC to the northern Indian Ocean. Nearly three-fourths of this amount $(7.8 \mathrm{Tg})$ reaches to the Bay of Bengal, while the Arabian Sea receives only one-fourth $(2.5 \mathrm{Tg})$. This is consistent with the higher magnitude of freshwater discharge to the Bay of Bengal $\left(378 \mathrm{~km}^{3} \mathrm{yr}^{-1}\right)$ from the catchment area of about $970 \mathrm{~km} \times 10^{3} \mathrm{~km}$ than the Arabian Sea $\left(122 \mathrm{~km}^{3} \mathrm{yr}^{-1}\right.$ from the catchment area of $244 \mathrm{~km} \times 10^{3} \mathrm{~km}$ ). The total DIC exported by the Indian monsoonal rivers $\left(10.3 \mathrm{Tg} \mathrm{yr}^{-1}\right)$ is lower than the DIC exported by the American (61.4 $\mathrm{Tg} \mathrm{yr}^{-1}$ ) and African $\left(17.7 \mathrm{Tg} \mathrm{yr}^{-1}\right)$ rivers and major rivers draining to the tropical Atlantic from South America and Africa (53 $\mathrm{Tg} \mathrm{yr}^{-1}$; Araujo et al., 2014). It is mainly due to the fact that freshwater discharge from the Indian monsoonal rivers is very low $\left(\sim 500 \mathrm{~km}^{3} \mathrm{yr}^{-1}\right)$ compared to the American $\left(11799 \mathrm{~km}^{3} \mathrm{yr}^{-1}\right)$ and African $\left(3786 \mathrm{~km}^{3} \mathrm{yr}^{-1}\right)$ rivers. However, the Indian monsoonal rivers are exporting disproportionately higher DIC, because they account for only $1.3 \%$ of the global river discharge but export $2.5 \%$ of the global river- ine DIC to the oceans $\left(400 \mathrm{Tg} \mathrm{yr}^{-1}\right)$. Though American and African rivers account for $30 \%$ and $10 \%$ of the global river discharge, they export only $15 \%$ and $4.4 \%$ of global riverine DIC to oceans, respectively. A disproportionately higher DIC flux from the Indian rivers could be due to relatively higher weathering rates of silicate and carbonate minerals in their drainage basins (Das et al., 2005; Gurumurty et al., 2012; Pattanaik et al., 2013). Higher DIC fluxes from the tropical regions are mainly attributed to the favorable climatic conditions, lithology and land use change (Huang et al., 2012) of this region for higher dissolution.

Krishna et al. (2015) reported that Indian monsoonal rivers export $2.32 \mathrm{Tg} \mathrm{yr}^{-1}$ of dissolved organic carbon (DOC) to the northern Indian Ocean. The total fluvial dissolved carbon flux (DIC + DOC) would be $12.6 \mathrm{Tg} \mathrm{yr}^{-1}$, to which DIC flux contributed up to $\sim 81 \%$. The predominance of DIC has also been found in rivers elsewhere in the world, for example, in British rivers (Jarvie et al., 2017) and high-altitude Swedish rivers (Campeau et al., 2017). Since the catchment area of the Indian monsoonal rivers ranged widely, from as low as $1 \mathrm{~km} \times 10^{3} \mathrm{~km}$ to as high as $313 \mathrm{~km} \times 10^{3} \mathrm{~km}$, the export fluxes of DIC were normalized with the catchment area of the river (yield) in order to examine various factors controlling the DIC export to the northern Indian Ocean.

\subsection{Yield of DIC from the Indian monsoonal rivers}

The yield of DIC found in this study (mean $8.7 \pm$ $5.2 \mathrm{~g} \mathrm{~m}^{-2} \mathrm{yr}^{-1}$ ) is close to those found in rivers from the tropical region of Asia but is significantly higher than those reported from tropical region of the American and African continents (Huang et al., 2012). The yield was highest (8.8 \pm $5.6 \mathrm{~g} \mathrm{~m}^{-2} \mathrm{yr}^{-1}$ ) in rivers from the SW region of India, despite the fact that they export relatively lower DIC $\left(0.3 \mathrm{Tg} \mathrm{yr}^{-1}\right)$ due to their low volume of discharge $\left(46 \mathrm{~km}^{3} \mathrm{yr}^{-1}\right)$ and relatively smaller catchment $\left(20 \mathrm{~km} \times 10^{3} \mathrm{~km}\right)$ than the rivers from SE, NE and NW regions of India (Table 1). DIC yield showed a significant positive correlation with the volume of discharge $\left(r^{2}=0.67, p<0.001\right.$; Fig. 6a) in medium-sized rivers, and no such relationship was found in the major rivers. Significant negative relationship was observed between DIC yield and catchment area of river $\left(r^{2}=-0.49, p<0.001-\right.$ Fig. $6 \mathrm{~b} ; r^{2}=-0.43, p<0.001-$ Fig. $6 \mathrm{c}$; for medium-sized and major rivers, respectively), suggesting that the smaller rivers export more DIC per unit area of catchment compared to the major river systems, and thus inclusion of DIC data from medium-sized rivers in the world significantly alters the global estimations of DIC. A fairly good linear relationship between the yield of DIC and the intensity of precipitation $\left(r^{2}=0.43, p<0.01-\right.$ Fig. $\left.6 \mathrm{~d}\right)$ was observed only in the rivers which receives $>2000 \mathrm{~mm}$ of annual mean precipitation. Higher precipitation over the catchment increases the yield of DIC, because the dense precipitation enhances the extraction of DIC from soils and rocks in their catchment. Therefore, high precipitation $(\sim 3000 \mathrm{~mm})$ over the small 

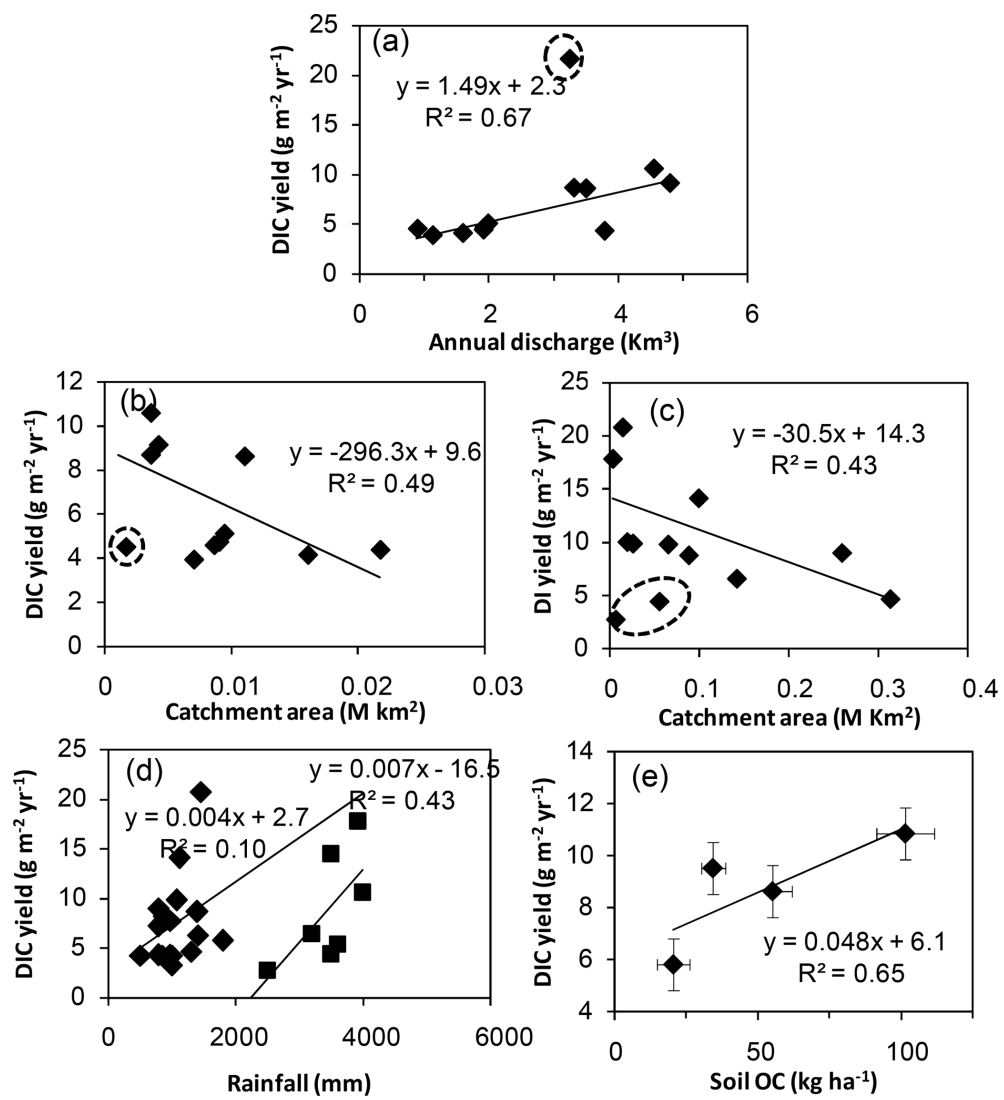

Figure 6. Significant relationships of dissolved inorganic carbon (DIC) yield with (a) river discharge in medium estuaries, (b) catchment areas of the medium-sized rivers, (c) catchment areas of the major rivers, (d) rainfall over the catchment of all the rivers sampled and (e) soil organic carbon (OC) content in catchments of the Indian monsoonal rivers studied. Since the data on soil OC are not available for each watershed, (e) was plotted using the available soil OC data on regional scale (NW, SW, SE and NE regions of India). Hence, it contains only four points.

catchment $\left(20 \mathrm{~km} \times 10^{3} \mathrm{~km}\right)$ could have increased DIC yield from the rivers of the SW region of India.

Sreenivas et al. (2016) and Krishwan et al. (2009) found that the soil organic and inorganic carbon contents in the surface $(100 \mathrm{~cm})$ soils in the catchment of rivers in the SW region were higher and lower, respectively, than the catchments of the rivers from the SE, SW and NE regions of India. Decomposition of soil organic matter releases excess $\mathrm{CO}_{2}$ that increases $\mathrm{CO}_{2}$ in soils, leading to the formation of acidic conditions in soils. This would increase the DIC yield by more dissolution of soil carbonates and chemical weathering of carbonate and silicate rocks (Zou et al., 2016). A significant linear correlation was found between soil organic carbon content and DIC yield in this study $\left(r^{2}=0.65\right.$, $p<0.001$; Fig. $6 \mathrm{e})$, suggesting that higher soil organic carbon in the catchment of the rivers from the SW region could have elevated the yield of DIC from rivers of this region. The basin-scale studies are, however, required for a comprehensive understanding of the influence of environmental and anthropogenic factors on export fluxes and yield of DIC from the Indian monsoonal rivers.

\section{Summary}

In order to examine the spatial variability in the sources and distribution of dissolved inorganic carbon (DIC) in the Indian monsoonal rivers, and to estimate their export fluxes of DIC to the northern Indian Ocean, we sampled a total of 27 major and medium-sized rivers during the wet period. An order of magnitude variability was found in DIC concentrations among the rivers sampled $\left(3.4-73.6 \mathrm{mg} \mathrm{L}^{-1}\right)$, with a lower mean concentration of $6.6 \pm 2.1 \mathrm{mg} \mathrm{L}^{-1}$ in rivers located in the SW region of India. It is attributed to significant spatial variability in the size of rivers, precipitation pattern, pollution and lithology in their catchments. The approximated $\delta^{13} \mathrm{C}$ of DIC source from the Keeling and Miller-Tans plots $\left(-2.0 \%\right.$ and $-3.0 \%$, respectively), and the calculated $\delta^{13} \mathrm{C}$ of $\mathrm{CO}_{2}$ suggested that DIC in the Indian rivers mainly originates from chemical weathering of carbonate minerals but is largely affected by autotrophic production in rivers from the southeastern region of India and heterotrophic decomposition of organic matter in rivers from other regions of India. Indian monsoonal rivers together export $\sim 10.3 \mathrm{Tg} \mathrm{yr}^{-1}$ of 
DIC to the northern Indian Ocean, of which $7.8 \mathrm{Tg} \mathrm{yr}^{-1}$ enters into to the Bay of Bengal, while the Arabian Sea receives only $2.5 \mathrm{Tg} \mathrm{yr}^{-1}$. It is mainly attributed to the volume of river discharge, as the former receives $\sim 378 \mathrm{~km}^{3} \mathrm{yr}^{-1}$ while the latter receives only $122 \mathrm{~km}^{3} \mathrm{yr}^{-1}$ from the Indian monsoonal rivers. Dense rainfall and higher soil organic carbon content in the catchment of rivers from the SW region than in the catchment of the other Indian rivers resulted in the highest yield of DIC from the former than the latter.

Data availability. The data set used in the current study can be obtained from the corresponding author by an e-mail request.

Author contributions. MSK and VVSSS planned, executed and prepared the paper. RV, MHKP and URK were involved in the sample collection, data analysis, graphical presentation and scientific discussions.

Competing interests. The authors declare that they have no conflict of interest.

Special issue statement. This article is part of the special issue "Human impacts on carbon fluxes in Asian river systems". It is not associated with a conference.

Acknowledgements. We would like to thank the director of the CSIR - National Institute of Oceanography (NIO), Goa, and the scientist in charge of the NIO Regional Centre in Visakhapatnam for their kind support and encouragement. We also acknowledge Maripi Dileep Kumar, NIO Goa, for his guidance and encouragement. The work is part of the Council of Scientific and Industrial Research (CSIR) funded research project. This publication has the NIO contribution number 6339 .

Edited by: Gwenaël Abril

Reviewed by: Garuda V. M. Gupta and two anonymous referees

\section{References}

Abongwa, P. T. and Atekwana, E. A.: Assessing the temporal evolution of dissolved inorganic carbon in waters exposed to atmospheric $\mathrm{CO}_{2}$ : a laboratory approach, J. Hydrol., 505, 250-265, 2014.

Araujo, M., Noriega, C., and Lefevre, N.: Nutrients and carbon fluxes in the estuaries of major rivers flowing into the tropical Altantic, Front. Mar. Sci., 1, 1-16, 2014.

Barber, R. T., Marra, J., Bidigare, R. C., Codispoti, L. A., Halpern, D., Johnson, Z., Latasa, M., Goericke, R., and Smith, S. L.: Primary productivity and its regulation in the Arabian Sea during 1995, Deep-Sea Res. Pt. II, 48, 1127-1172, 2001.

Berner, R. A., Lasaga, A. C., and Garrels, R. M.: The carbonatesilicate geochemical cycle and its effect on atmospheric carbon dioxide over the past 100 million years, Am. J. Sci., 283, 641683, 1983.

Bhavya, P. S., Sanjeev Kumar, Gupta, G. V. M., Sudharma, K. V., and Sudheesh, V.: Spatio-temporal variation in $\delta^{13} \mathrm{C}_{\mathrm{DIC}}$ of a tropical eutrophic estuary (Cochin estuary, India) and adjacent Arabian Sea, Cont. Shelf Res., 153, 75-85, https://doi.org/10.1016/j.csr.2017.12.006, 2018.

Bouillon, S., Abril, G., Borges, A. V., Dehairs, F., Govers, G., Hughes, H. J., Merckx, R., Meysman, F. J. R., Nyunja, J., Osburn, C., and Middelburg, J. J.: Distribution, origin and cycling of carbon in the Tana River (Kenya): a dry season basin-scale survey from headwaters to the delta, Biogeosciences, 6, 2475-2493, https://doi.org/10.5194/bg-6-2475-2009, 2009.

Brunet, F., Gaiero, D. M., Probst, J. L., Depetris, P. J., GauthierLafaye, F., and Stille, P.: $\delta^{13} \mathrm{C}$ tracing of dissolved inorganic carbon sources in Patagonian rivers (Argentina), Hydrol. Process., 19, 3321-3344, https://doi.org/10.1002/hyp.5973, 2005.

Cai, W. J., Guo, X. H., Chen, C. T. A., Dai, M. H., Zhang, L. J., Zhai, W. D., Lohrenz, S. E., Yin, K. D., Harrison, P. J., and Wang, Y. C.: A comparative overview of weathering intensity and $\mathrm{HCO}_{3}$ flux in the world's major rivers with emphasis on the Changjiang, Huanghe, Zhujiang (Pearl) and Mississippi Rivers, Cont. Shelf Res., 28, 1538-1549, 2008.

Campeau, A., Wallin, M. B., Giesler, R., Löfgren, S., Mörth, C.-M., Schiff, S., Venkiteswaran, J. J., and Bishop, K.: Multiple sources and sinks of dissolved inorganic carbon across Swedish streams, refocusing the lens of stable $\mathrm{C}$ isotopes, Nature Sci. Rep., 7, 9158, https://doi.org/10.1038/s41598-017-09049-9, 2017.

Carritt, D. E. and Carpenter, J. H.: Comparison and evaluation of currently employed modifications of the Winkler method for determining dissolved oxygen in seawater: A NASCO report, J. Mar. Res., 24, 286-318, 1966.

Catalan, N., Marce, R., Kothawala, D. N., and Tranvik, L. J. Organic carbon decomposition rates controlled by water retention time across inland waters, Nat. Geosci., 9, 501-504, https://doi.org/10.1038/ngeo2720, 2016.

Central Water Commission: Integrated Hydrological Data Book, New Delhi, India, 383 pp., 2006.

Central Water Commission: Integrated Hydrological Data Book, New Delhi, India, 680 pp., 2012.

Coplen, T. B.: New guidelines for reporting stable hydrogen, carbon and oxygen isotope-ratio data, Geochim. Cosmochim. Ac., 60, 3359-3360, 1996.

Coplen, T. B., Hopple, J. A., Böhlke, J. K., Peiser, H. S., Rieder, S. E., Krouse, H. R., Rosman, K. J. R., Ding, T., Vocke Jr., R. D., Révész, K. M., Lamberty, A., Taylor, P., and De Bièvre, P.: Compilation of minimum and maximum isotope ratios of selected elements in naturally occurring terrestrial materials and reagents, U.S. Department of the Interior and U.S. Geological Survey, USA, 2002.

Crawford, J. T., Lottig, N. R., Stanely, E. H. Walker, J. F., Hanson, P. C., Finlay, J. C., and Strieg, R. G.: $\mathrm{CO}_{2}$ and $\mathrm{CH}_{4}$ emissions from streams in a lake-rich landscape: Patterns, controls, and regional significance, Global Biogeochem. Cy., 28, 197-210, https://doi.org/10.1002/2013gb004661, 2014.

Das, A., Krishnaswami, S., and Bhattacharya, S. K.: Carbon isotope ratio of dissolved inorganic carbon (DIC) in rivers draining the Deccan Traps, India: Sources of DIC 
and their magnitudes, Earth Planet. Sc. Lett., 236, 419-429, https://doi.org/10.1016/j.epsl.2005.05.009, 2005.

Deines, P., Langmuir, D., and Harmon, R. S.: Stable carbon isotope ratios and the existence of a gas phase in the evolution of carbonate ground waters, Geochim. Cosmochim. Ac., 38, 1147-1164, https://doi.org/10.1016/0016-7037(74)90010-6, 1974.

Deirmendjian, L. and Abril, G.: Carbon dioxide degassing at the groundwater-stream atmosphere interface: isotopic equilibration and hydrological mass balance in a sandy watershed, J. Hydrol., 558, 129-143, https://doi.org/10.1016/j.jhydrol.2018.01.003, 2018.

Dessert, C., Dupre, B., Francois, L. M., Schott, J., Gaillardet, J., Chakrapani, G., and Bajpai, S.: Erosion of Deccan Traps determined by river geochemistry: impact on the global climate and the ${ }^{87} \mathrm{Sr} /{ }^{86} \mathrm{Sr}$ ratio of seawater, Earth Planet. Sc. Lett., 188, 459-474, 2001.

Finlay, J. C.: Controls of stream water dissolved inorganic carbon dynamics in a forested watershed, Biogeochemistry, 62, 231252, 2003.

Finlay, J. C.: Patterns and controls of lotic algal stable carbon isotope ratios, Limnol. Oceanogr., 49, 850-861, 2004.

Gaillardet, J., Dupre, B., Louvat, P., and Allegre, C. J.: Global silicate weathering and $\mathrm{CO}_{2}$ consumption rates deduced from the chemistry of large rivers, Chem. Geol., 159, 3-30, 1999.

Garcia, E. H. and Gordon, L. I.: Oxygen solubility in seawater better fitting equations, Limnol. Oceanogr., 37, 1307-1312, https://doi.org/10.4319/lo.1992.37.6.1307, 1992.

Gauns, M., Madhupratap, M., Ramaiah, N., Jyothibabu, R., Fernandes, V., Paul, J. T., and Kumar, S. P.: Comparative accounts of biological productivity characteristics and estimates of carbon fluxes in the Arabian Sea and the Bay of Bengal, Deep-Sea Res. Pt. II, 52, 2003-2017, 2005.

Giesler, R., Morth, C.-M., Karlsson, J., Lundin, E. J., Lyon, S. W., and Humborg, C.: Spatiotemporal variations of $p \mathrm{CO}_{2}$ and $\delta^{13} \mathrm{C}$-DIC in subarctic streams in northern Sweden, Global Biogeochem. Cy., 27, 176-186, https://doi.org/10.1002/gbc.20024, 2013.

Gupta, G. V. M., Sarma, V. V. S. S., Robin, R. S., Raman, A. V., Jai Kumar, M., Rakesh, M., and Subramanian, B. R.: Influence of net ecosystem metabolism in transferring riverine organic carbon to atmospheric $\mathrm{CO}_{2}$ in a tropical coastal lagoon (Chilka Lake, India), Biogeochemistry, 87, 265-285, https://doi.org/10.1007/s10533-008-9183-x, 2008.

Gupta, G. V. M., Thottathil, S. D.,Balachandran, K. K., Madhu, N. V., Madeswaran, P., and Nair, S.: $\mathrm{CO}_{2}$ supersaturation and net heterotrophy in a tropical estuary (Cochin, India): influence of anthropogenic effect, Ecosystems, 12, 1145-1157, https://doi.org/10.1007/s10021-009-9280-2, 2009.

Gupta, H., Chakrapani, G. J., Selvaraj, K., and Kao, S.-J.: The fluvial geochemistry, contributions of silicate, carbonate and salinealkaline components to chemical weathering flux and controlling parameters: Narmada River (Deccan Traps), India, Geochim. Cosmochim. Ac., 75, 800-824, 2011.

Gurumurthy, G. P., Balakrishna, K., Riotte, J., Braun, J.-J., Audry, S., Shankar, H. N. U., and Manjunatha, B. R.: Controls on intense silicate weathering in a tropical river, southwestern India, Chem. Geol., 300-301, 61-69, 2012.

Hotchkiss, E. R., Hall Jr., R. O., Sponseller, R. A., Butman, D., Klaminder, J., Laudon, H., Rosvall, M., and Karlsson, J.:
Sources of and processes controlling $\mathrm{CO}_{2}$ emissions change with the size of streams and rivers, Nat. Geosci., 8, 696-699, https://doi.org/10.1038/Ngeo2507, 2015.

Huang, T.-H., Fu, Y.-H., Pan, P.-Y., and Arthur, C. T.: Fluvial carbon fluxes in tropical rivers, Curr. Opin. Environ. Sust., 4, 162-169, 2012.

Jarvie, H. P., King, S. M., and Neal, C.: Inorganic carbon dominates total dissolved carbon concentrations and fluxes in British rivers: Application of the THINCARB model - Thermodynamic modeling of inorganic carbon in freshwaters, Sci. Total Environ., 575, 496-512, 2017.

Joesoef, A., Kirchman, D. L., Sommerfield, C. K., and Cai, W.J.: Seasonal variability of the inorganic carbon system in a large coastal plain estuary, Biogeosciences, 14, 4949-4963, https://doi.org/10.5194/bg-14-4949-2017, 2017.

Keeling, C. D.: The concentration and isotopic abundances of atmospheric carbon dioxide in rural areas, Geochim. Cosmochim. Ac., 13, 322-334, https://doi.org/10.1016/0016-7037(58)900334, 1958.

Kishwan, J., Pandey, R., and Dhadwal, V. K.: India's forest and tree cover: Contribution as a carbon sink, Tech. Pap. 130, ICFRE BL23, 2009.

Kokic, J., Wallin, M. B., Chmiel, H. E., Denfeld, B. A., and Sobek, S.: Carbon dioxide evasion from headwater systems strongly contributes to the total export of carbon from a small boreal lake catchment, J. Geophys. Res. Biogeosciences, 120, 13-28, https://doi.org/10.1002/2014jg002706, 2015.

Krishna, M. S., Prasad, V. R., Sarma, V. V. S. S., Reddy, N. P. C., Hemalatha, K. P. J., and Rao, Y. V.: Fluxes of dissolved organic carbon and nitrogen to the northern Indian Ocean from the Indian monsoonal rivers, J. Geophys. Res.-Biogeo., 120, 2067-2080, 2015.

Kumar, R., Singh, R. D., and Sharma, K. D.: Water resources of India, Curr. Sci. India, 89, 794-811, 2005.

Land, L. S.: The isotopic and trace element geochemistry of dolomite, in: the state of the art, Concepts and Models of Dolomitization, edited by: Zenger, D. H., Dunham, J. B., and Ethington, R. A., SEPM Special Publication No. 28, 63, 485, https://doi.org/10.2110/pec.80.28.0087, 1980.

Laskar, A. H., Gandhi, N., Thirumalai, K., Yadava, M. G., Ramesh, R., Mahajan, R. R., and Kumar, D.: Stable carbon isotopes in dissolved inorganic carbon: extraction and implications for quantifying the contributions from silicate and carbonate weathering in the Krishna River system during peak discharge, Isot. Environ. Healt. S., 50, 156-168, 2014.

Löfgren, S., Froberg, M., Yu, J., Nisell, J., and Ranneby, B.: Water chemistry in 179 randomly selected Swedish headwater streams relatedto forest production, clear-felling and climate, Environ Monit Assess., 186, 8907-8928, https://doi.org/10.1007/s10661014-4054-5, 2014.

Ludwig, W., Amiotte-Suchet, P., Munhoven, G., and Probst, J. L.: Atmospheric $\mathrm{CO}_{2}$ consumption by continental erosion: presentday controls and implications for the last glacial maximum, Global Planet. Change, 17, 107-120, 1998.

Madhupratap, M., Prasanna Kumar, S., Bhattathiri, P. M. A., Kumar, M. D., Raghukumar, S., Nair, K. K. C., and Ramaiah, N.: Mechanism of the biological response to winter cooling in the northeastern Arabian Sea, Nature, 384, 549-552, 1996. 
Mayorga, E., Aufdenkampe, A., Masiello, C. A., Krusche, A. V., Hedge, J. I., Quay, P. D., Richey, J. E., and Thomas, A. B.: Young organic matter as a source of carbon dioxide outgassing from Amazonian rivers, Nature, 436, 538-541, https://doi.org/10.1038/nature03880, 2005.

Meybeck, M.: Global chemical weathering of surficial rocks estimated from river dissolved loads, Am. J. Sci., 287, 401-428, 1987.

Meybeck, M. and Ragu, A.: GEMS/water contribution to the Global Register of River Inputs (GLORI), Provisional Final Rep., UNEP/WHO/UNESCO, Geneva, Switzerland, 245 pp., 1995.

Meybeck, M. and Ragu, A.: River discharges to the oceans. An assessment of suspended solids, major ions, and nutrients, Environ. Inf. and Assess. Rep., 240, https://doi.org/10.1594/PANGAEA.804574, 1996.

Meybeck, M. and Vorosmarty, C. J.: Global transfer of carbon by rivers, Global Change News Lett., 37, 18-19, 1999.

Miller, J. B. and Tans, P. P.: Calculating isotopic fractionation from atmospheric measurements at various scales, Tellus B, 55, 207214, https://doi.org/10.1034/j.1600-0889.2003.00020.x, 2003.

Mook, W. and Tan, F.: Stable carbon isotopes in rivers and estuaries, Biogeochemistry of major world rivers, Wiley, Chichester, UK, 42, 245-264, 1991.

Muduli, P., Vardhan, K. V., Robin, S. RCharankumar, B., Sivaji, P., Akkur, R., Gollapalli, R., Subramanian, B. R.: Distribution of dissolved inorganic carbon and net ecosystem production in a tropical brackish water lagoon, India. Cont. Shelf. Res., 64, 7587, https://doi.org/10.1016/j.csr.2013.05.014, 2013

Mukhopadhyay, S. K., Biswas, H., De, T. K., Sen, S., and Jana, T. $\mathrm{K}$.: Seasonal effects on the air-water carbon dioxide exchange in the Hooghly estuary, NE coast of Bay of Bengal, India, J. Environ. Monitor., 4, 549-552, 2002.

Muraleedharan, P. M. and Prasanna Kumar, S.: Arabian Sea upwelling - A comparison between coastal and open ocean regions, Curr. Sci. India, 71, 842-846, 1996.

O'Leary, M. H.: Carbon Isotopes in Photosynthesis, BioScience, 38, 328-336, https://doi.org/10.2307/1310735, 1988.

Opsahl, S. P. and Zepp, R. G.: Photochemically-induced alteration of stable carbon isotope ratios $\left(\delta^{13} \mathrm{C}\right)$ in terrigenous dissolved organic carbon, Geophys. Res. Lett., 28, 2417-2420, https://doi.org/10.1029/2000g1012686, 2001.

Öquist, M. G., Wallin, M., Seibert, J., Bishop, K., and Laudon, H.: Dissolved inorganic carbon export across the soil/stream interface and its fate in a boreal headwater stream. Environ. Sci. Tech., 43, 7364-7369, https://doi.org/10.1021/es900416h, 2009.

Parker, S. R., Poulson, S. R., Gammons, C. H., and DeGrandpre, M. D.: Biogeochemical controls on diel cycling of stable isotopes of dissolved $\mathrm{O}_{2}$ and dissolved inorganic carbon in the Big Hole River, Montana, Environ. Sci. Technol., 39, 7134-7140, https://doi.org/10.1021/es0505595, 2005.

Parker, S. R., Poulson, S. R., Smith, M. G., Weyer, C. L., and Bates, K. M.: Temporal variability in the concentration and stable carbon isotope composition of dissolved inorganic and organic carbon in two Montana, USA Rivers, Aquat Geochem., 16, 61-84, https://doi.org/10.1007/s10498-009-9068-1, 2010.

Pataki, D. E., Ehleringer, J. R., Flanagan, L. B., Yakir, D., Bowling, D. R., Still, C. J., Buchmann, N., Kaplan, J. O., and Berry, J. A.: The application and interpretation of Keeling plots in terres- trial carbon cycle research, Global Biogeochem. Cy., 17, 1022, https://doi.org/10.1029/2001GB001850, 2003.

Pattanaik, J. K., Balakrishnan, S., Bhutani, R., and Singh, P.: Estimation of weathering rates and $\mathrm{CO}_{2}$ drawdown based on solute load: Significance of granulites and gneisses dominated weathering in the Kaveri River basin, Southern India, Geochim. Cosmochim. Ac., 121, 611-636, 2013.

Pattanaik, S., Sahoo, R. K., Satapathy, D. R., Panda, C. R., Choudhury, S. B., and Mohapatra, P.: Intra-annual Variability of $\mathrm{CO}_{2}$ Flux in the Mahanadi Estuary - A Tropical Estuarine System, India. Ann. Mar. Sci., 1, 005-012, 2017.

Polsenaere, P. and Abril, G.: Modelling $\mathrm{CO}_{2}$ degassing from small acidic rivers using water $p \mathrm{CO}_{2}, \mathrm{DIC}$ and $\delta^{13}$ C-DIC data. Geochim. Cosmochim. Ac., 91, 220-239, https://doi.org/10.1016/j.gca.2012.05.030, 2012.

Prasanna Kumar, S., Muraleedharan, P. M., Prasad, T. G., Gauns, M., Ramaiah, N., de Souza, S. N., Sardesai, S., and Madhupratap, M.: Why is the Bay of Bengal less productive during summer monsoon compared to the Arabian Sea?, Geophys. Res. Lett., 29, 2235, https://doi.org/10.1029/2002GL016013, 2002.

Prasanna Kumar, S., Nuncio, M., Narvekar, J., Kumar, A., Sardessai, S., DeSousa, S. N., Gauns, M., Ramaiah, N., and Madhupratap, M.: Are eddies nature's trigger to enhance biological productivity in the Bay of Bengal?, Geophys. Res. Lett., 31, L07309, https://doi.org/10.1029/2003GL019274, 2004.

Quay, P. D., Wilbur, D. O., Richey, J. E., Hedges, J. I., Devol, A. H., and Victoria, R.: Carbon cycling in the Amazon River: Implications from the ${ }^{13} \mathrm{C}$ compositions of particles and solutes, Limnol. Oceanogr., 37, 857-871, https://doi.org/10.4319/lo.1992.37.4.0857, 1992.

Raymond, P. A. and Cole, J. J.: Increase in the export of alkalinity from North America's largest river, Science, 301, 88-91, https://doi.org/10.1126/science.1083788, 2003.

Raymond, P. A., Oh, N. H., Turner, R. E., and Broussard, W.: Anthropogenically enhanced fluxes of water and carbon from the Mississippi River, Nature, 451, 449-452, https://doi.org/10.1038/Nature06505, 2008.

Raymond, P. A., Hartmann, J., Lauerwald, R., Sobek, S., McDonald, C., Hoover, M., Butman, D., Striegl, R., Mayorga, E., Humborg, Ch., Kortelainen, P., Durr, H., Meybeck, M., Ciais, P., and Cuth, P.: Global carbon dioxide emissions from inland waters, Nature, 503, 355-359, https://doi.org/10.1038/nature12760, 2013.

Richey, J. E., Melack, J. M., Aufdenkampe, A. K., Ballester, V. M., and Hess, L. L.: Outgassing from Amazonian rivers and wetlands as a large tropical source of atmospheric $\mathrm{CO}_{2}$, Nature, 416, 617620, 2002.

Samanta, S., Dalai, T. K., Pattanai K. J. K., Rai, S. K., and Mazumdar, A.: Dissolved inorganic carbon (DIC) and its $\delta^{13} \mathrm{C}$ in the Ganga (Hooghly) River estuary, India: Evidence of DIC generation via organic carbon degradation and carbonate dissolution, Geochim. Cosmochim. Ac., 165, 226-248, 2015.

Sarma, V. V. S. S., Kumar, M. D., and Manerikar, M.: Emission of carbon dioxide from a tropical estuarine system, Goa, India, Geophys. Res. Lett., 28, 1239-1242, https://doi.org/10.1029/2000GL006114, 2001.

Sarma, V. V. S. S., Kumar, N. A., Prasad, V. R., Venkataramana, V., Appalanaidu, S., Sridevi, B., Kumar, B. S. K., Bharati, M. D., Subbaiah, Ch. V., Acharyya, T., Rao, G. D., Viswanadham, R., 
Gawade, L., Manjary, D. T., Kumar, P. P., Rajeev, K., Reddy, N. P. C., Sarma, V. V., Kumar, M. D., Sadhuram, Y., and Murty, T. V. R.: High $\mathrm{CO}_{2}$ emissions from the tropical Godavari estuary (India) associated with monsoon river discharges, Geophys. Res. Lett., 38, L08601, https://doi.org/10.1029/2011GL046928, 2011.

Sarma, V. V. S. S., Viswanadham, R., Rao, G. D., Prasad, V. R., Kumar, B. S. K., Naidu, S. A. Kumar, N. A., Rao, D. B., Sridevi, T., Krishna, M. S., Reddy, N. P. C., Sadhuram, Y., and Murty, T. V. R.: Emission of carbon dioxide from the Indian monsoonal estuaries, Geophys. Res. Lett., 39, L03602, https://doi.org/10.1029/2011GL050709, 2012.

Shetye, S. R., Gouveia, A. D., and Shenoi, S. S. C.: Circulation and water masses of the Arabian Sea, P. Indian A. S.-Earth, 103, 107-123, 1994.

Shin, W. J., Chung, G. S., Lee, D., and Lee, K. S.: Dissolved inorganic carbon export from carbonate and silicate catchments estimated from carbonate chemistry and $\delta^{13} \mathrm{C}_{\mathrm{DIC}}$, Hydrol. Earth Syst. Sci., 15, 2551-2560, https://doi.org/10.5194/hess-15-25512011, 2011.

Singh, S. K., Sarin, M. M., and France-Lanord, C.: Chemical erosion in the eastern Himalaya: Major ion composition of the Brahmaputra and ${ }^{13} \mathrm{C}$ of dissolved inorganic carbon, Geochim. Cosmochim. Ac., 69, 3573-3588, 2005.

Smith S. L.: Understanding the Arabian Sea: reflections on the 1994-1996 Arabian Sea expedition, Deep-Sea Res. Pt. II, 48, 1385-1402, 2001.

Solomon, D. K. and Cerling, T. E.: The annual carbon dioxide cycle in a montane soil: observations, modeling and implications for weathering, Water Resour. Res., 23, 2257-2265, 1987.

Soman, M. K. and Kumar, K. K.: Some aspects of daily rainfall distribution over India during the southwest monsoon season, Int. J. Climatol., 19, 299-311, 1990.

Sreenivas, K., Dadhwal, V. K., Suresh, K., Sri Harsha, G., Tarik, M., Sujatha, G, Suresh, J. R. G., Fyzee, M., and Ravisankar, T.: Digital mapping of soil organic and inorganic carbon status in India, Geoderma, 269, 160-173, https://doi.org/10.1016/j.geoderma.2016.02.002, 2016.

Sridevi, B., Sarma, V. V. S. S., Murty, T. V. R., Sadhuram, Y., Reddy, N. P. C., Vijayakumar, K., Raju, N. S. N., Jawahar Kumar, C., Raju, Y. S. N., Luis, R., Kumar, M. D., and Prasad, K. V. S. R.: Variability in stratification and flushing times of the Gautami-Godavari estuary, India, J. Earth. Syst. Sci., 124, 9931003, 2015.

Subramanian, V.: Sediment load of Indian rivers, Curr. Sci. India, 64, 928-930, 1993.

Suzuki, R. and Ishimaru, T.: An improved method for the determination of phytoplankton chlorophyll using N,N-dimethyl formamide, J. Oceanogr., 46, 190-194, 1990.

Tamooh, F., Borges, A. V., Meysman, F. J. R., Van Den Meersche, K., Dehairs, F., Merckx, R., and Bouillon, S.: Dynamics of dissolved inorganic carbon and aquatic metabolism in the Tana River basin, Kenya, Biogeosciences, 10, 6911-6928, https://doi.org/10.5194/bg-10-6911-2013, 2013.
Tamse, S., Ogrinc, N., Walter, L. M, Turk, D., and Faganeli, J.: River Sources of Dissolved Inorganic Carbon in the Gulf of Trieste (N Adriatic): Stable Carbon Isotope Evidence, Estuar. Coast., 38, 151-164, https://doi.org/10.1007/s12237-014-9812-7, 2014.

Vähätalo, A. V. and Wetzel, R. G.: Long-term photochemical and microbial decomposition of wetlandderived dissolved organic matter with alteration of ${ }^{13} \mathrm{C}:{ }^{12} \mathrm{C}$ mass ratio, Limnol. Oceanogr., 53, 1387-1392, https://doi.org/10.4319/lo.2008.53.4.1387, 2008.

Varkey, M. J., Murty, V. S. N., and Suryanarayana, A.: Physical oceanography of the Bay of Bengal and Andaman Sea, Oceanogr. Mar. Biol., 34, 1-70, 1996.

Venkiteswaran, J. J., Schiff, S. L., and Wallin, M. B.: Large Carbon Dioxide Fluxes from Headwater Boreal and Sub-Boreal Streams, PLoS ONE, 9, e101756, https://doi.org/10.1371/journal.pone.0101756, 2014.

Viers, J., Oliva, P., Dandurand, J. L., Dupré, B., Gaillardet, J., Heinrich, D. H., and Karl, K. T.: Chemical weathering rates, $\mathrm{CO}_{2}$ consumption, and control parameters deduced from the chemical composition of Rivers, Treatise on Geochemistry Pergamon, Oxford, UK, 2007.

Vijith, V., Sundar, D., and Shetye, S. R.: Time-dependence of salinity in monsoonal estuaries, Estuar. Coast. Shelf S., 85, 601-608, https://doi.org/10.1016/j.ecss.2009.10.003, 2009.

Waldron, S., Scott, E. M., and Soulsby, C.: Stable isotope analysis reveals lower-order river dissolved inorganic carbon pools are highly dynamic, Environ. Sci. Technol., 41, 6156-6162, https://doi.org/10.1021/es0706089, 2007.

Wallin, M. B., Grabs, T., Buffam, I., Laudon, H., Agren, A., Oquist, M. G., and Bishop, K.: Evasion of $\mathrm{CO}_{2}$ from streams - The dominant component of the carbon export through the aquatic conduit in a boreal landscape, Glob. Change Biol., 19, 785-797, https://doi.org/10.1111/gcb.12083, 2013.

Wang, Z. A., Bienvenu, D. J., Mann, P. J., Hoering, K. A., Poulsen, J. R., Spencer, R. G. M., and Holmes, R. M.: Inorganic carbon speciation and fluxes in the Congo River, Geophys. Res. Lett., 40, 511-516, 2013.

Zeng, F.-W., Masiello, C. A., and Hockaday, W. C.: Controls on the origin and cycling of riverine dissolved inorganic carbon in the Brazos River, Texas, Biogeochemistry, 104, 275-291, https://doi.org/10.1007/s10533-010-9501-y, 2011.

Zhang, J.: Carbon isotope fractionation during gas-water exchange and dissolution of $\mathrm{CO}_{2}$, Geochim. Cosmochim. Ac., 59, 107114, https://doi.org/10.1016/00167-0379(59)1550d, 1995.

Zou, J.: Sources and Dynamics of Inorganic Carbon within the Upper Reaches of the Xi River Basin, Southwest China, PLoS One, 11, e0160964, https://doi.org/10.1371/journal.pone.0160964, 2016. 